B.G. Andryukov ${ }^{1,2^{*}}$, N.N. Besednova ${ }^{1}$, T.A. Kuznetsova ${ }^{1}$, T.S. Zaporozhets ${ }^{1}$, S.P. Ermakova ${ }^{3}$, T.N. Zvyagintseva ${ }^{3}$, E.A.Chingizova ${ }^{3}$, A.K. Gazha ${ }^{1}$, and T.P. Smolina ${ }^{1}$

\title{
SULFATED POLYSACCHARIDES FROM SEA ALGAE AS THE BASIS OF MODERN BIOTECHNOLOGIES FOR CREATING WOUND COVERINGS: CURRENT ACHIEVEMENTS AND COMING PROSPECTS
}

${ }^{1}$ Somov Research Institute of Epidemiology and Microbiology, Vladivostok, Russian Federation; ${ }^{2}$ Far Eastern Federal University (FEFU), Vladivostok, Russian Federation;

${ }^{3}$ Elyakov Pacific Institute of Bioorganic Chemistry (PIBOC) FEB RAS, Vladivostok, Russian Federation.

*Author-correspondent: Andryukov Boris G., e-mail: andrukov_bg@mail.ru

\section{Abstract}

Wound healing involves a complex cascade of cellular, molecular, and biochemical responses and signaling processes. It consists of successive interrelated phases, the duration of which depends on multifactorial processes. Wound treatment is a major healthcare issue that can be resolved by development of effective and affordable wound dressings based on natural materials and biologically active substances. Proper use of modern wound dressings can significantly accelerate wound healing with minimal cosmetic defects. The innovative biotechnologies for creating modern natural interactive dressings are based on sulfated polysaccharides from seaweeds with their unique structures and biological properties, the availability of their sources in the form of wild bushes, and in the form of aquaculture, as well as with a high potential for participation in process control wound healing. These natural biopolymers are a novel and promising biologically active source for designing wound dressings based on alginates, fucoidans, carrageenans, and ulvans, which serve as active and effective therapeutic tools. The aim of this review is to summarize available information about the modern wound dressing's technologies based on seaweed-derived polysaccharides, including those successfully implemented in commercial products, with the emphasis on promising and innovative designs. The further prospect of using marine biopolymers is related to the need to analyze the results of numerous in vitro and in vivo experiments, summarize clinical trial data, develop a scientifically based approach and relevant practical recommendations for the treatment of wounds.

Keywords: seaweed, sulfated polysaccharides, alginates, fucoidans, carrageenans, ulvans, wound dressing, wounds.

\section{Graphic abstract}

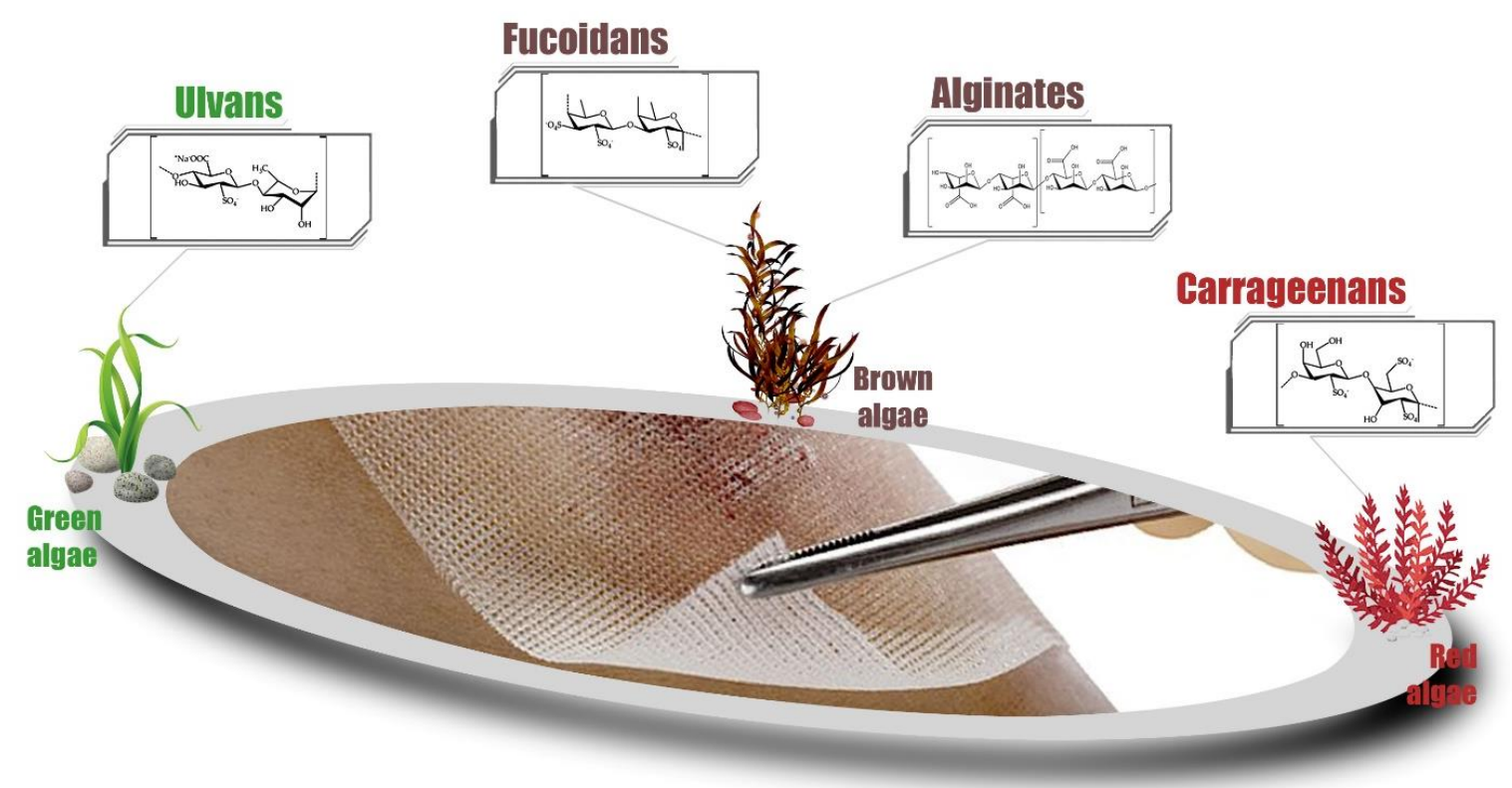




\section{Introduction}

Skin is one of the most important organs which protects the body from external stresses and pathogenic microorganisms, is involved in respiration, thermoregulation, and communication with the environment via receptors. Each human is constantly exposed to all kinds injured and wounds while being at home, at work, or as a result of an accident. After being inflicted, they reduce the quality of life and, therefore, any skin damage must be immediately and effectively treated through a dynamic mechanism of wound healing, which a process involving a complex cascade of cellular, molecular, and biochemical responses and signaling processes triggered in a certain sequence $[1,2]$.

Treatment of skin wounds has always been and remains a major healthcare and social issue. Every year, an immense number of people in the world get a countless number of wounds, injuries, burns, ulcers, and surgical wounds which require substantial funds and healthcare efforts for treatment. Therefore, invention of an effective wound dressing that would be affordable and easy to use is still an urgent problem in modern medicine [1, 3, 4].

The history of medicine is to a large extent is the history of search for the most perfect wound dressing using natural materials and substances for primary medical care and specialized treatment of skin wounds $[2,5,6]$. In recent decades, various approaches have been developed and implemented for this purpose, including the use of special wound dressings and coatings: polyurethane foam films, hydrocolloids, hydrogels, paraffin dressing, which provide moisture and exudate adsorption, as well as delivery of active drug molecules to wound. These dressings are now increasingly demanded in the market of medical expendable supplies [1, 3, 4, 7].

To date, the most effective treatment strategies for wound healing have been multifunctional types of wound dressings (bandages). Structurally, they include synthetic or natural biologically active substances (BAS) with mechanisms of anti-inflammatory, antimicrobial, immunostimulating, analgesic, and antioxidant action [1, 5]. Modern wound bandages are designed not only for covering skin damage, but their action is aimed also at minimizing possible medical complications and stimulating the healing phases of various wound types. Thus, the correct choice of wound dressing type with a specific mechanism of action is crucial for the successful treatment of certain wound $[4,5,8,9]$.

Synthetic products and materials have a high risk of side effects: allergic complications, toxic effects, the occurrence of microbial resistance $[3,5,10,11]$. Therefore, with the development of technologies for designing wound bandages, natural biopolymers, including those derived from marine organisms, become increasingly more valuable $[5,6,12]$.

The world's ocean are populated by a huge number of different organisms that differ in higher phylogenetic diversity from those that live on land. Thanks to many years of adaptation to 
various environmental conditions, marine hydrobionts, such as algae, mollusks, sponges, corals, produce unique biopolymers with extremely high biological activity [1, 3, 13-17].

In the present review, we focus on marine algae, a vast community of multicellular autotrophic organisms taxonomically organized into three large groups depending on the color of their thalli: Chlorophyta (green), Rhodophyta (red), and Phaeophyceae (brown). All of them are an inexhaustible source of various polysaccharides with qualities that meet the modern requirements to materials used in wound dressing designs: bioavailability, biocompatibility, nontoxicity, and lack of side effects during the process of wound healing $[10,12,15]$.

However, the widespread use of natural polysaccharides as a structural basis for wound dressings is still prevented by a number of factors. This is associated to a significant extent with the lack of knowledge about successful biomedical and experimental studies on the use of marine-derived biopolymers for wound healing, as well as the lack of a systematic approach to assessing their clinical effectiveness before introduction in clinical practice $[9,12,18]$. In addition, the question of standardizing of marine polysaccharides is still unresolved, and their structural diversity depends on the collection season, geographical location, and other factors [13, 18-20].

The aim of this review is to summarize available information about the modern wound dressing's technologies based on seaweed-derived polysaccharides, including those successfully implemented in commercial products, with the emphasis on promising and innovative designs.

\section{Wound healing process and phases}

A wound is a breach of integrity of the skin, mucous membrane, internal tissues, or an organ as a result of physical, thermal damage, or trophic disturbances [5, 11, 12, 21]. Any skin damage, whether it is a small cut or extensive and deep wound, needs care and treatment including such an important part as application (replacement) of bandage [11, 22, 23] (Fig. 1).

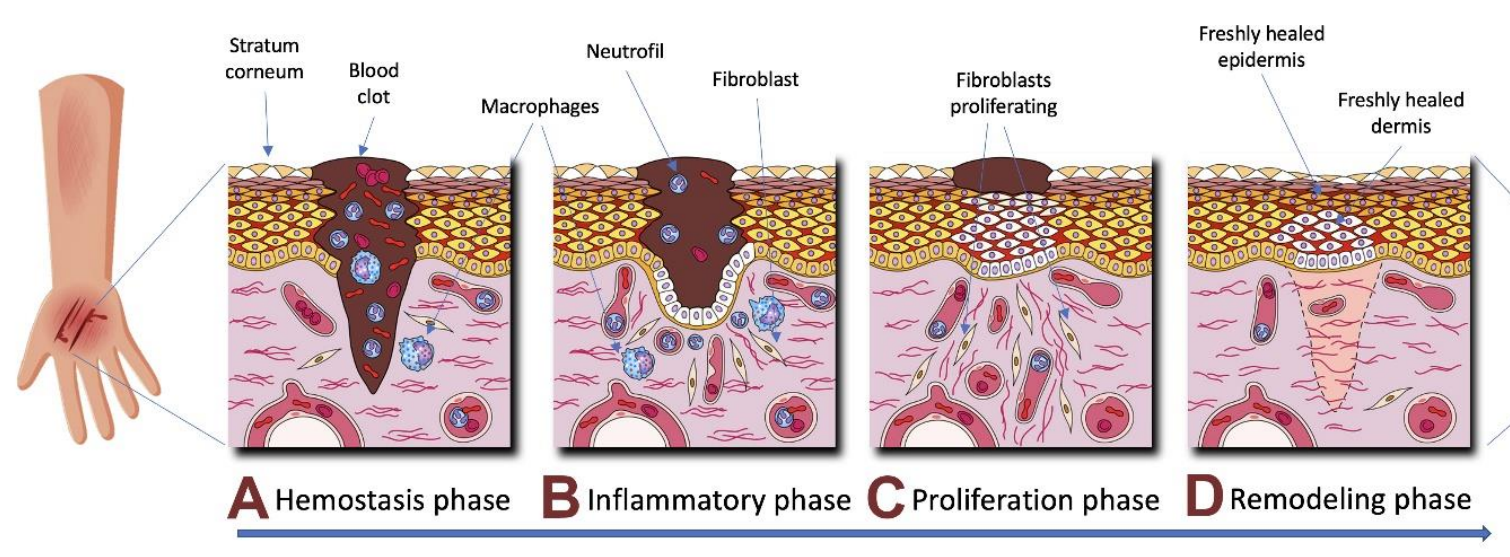

Fig. 1. The sequence of interconnected phases of the wounds healing process: coagulation (A), inflammation (B), proliferation (C) and tissue remodeling (D) 
Wound repair is one of the most complex biological processes that occur in human life. The dynamic pathogenetic process of healing of acute wounds depends on the balance of such factors as oxygenation, temperature, and $\mathrm{pH}[12,24-26]$. It consists of several successive and interrelated phases: coagulation (hemostasis), inflammation, fibroblast proliferation, and tissue remodeling [23, 27-30].

The initial stage is aimed at preventing excessive blood loss, for which it triggers the hemostatic mechanisms in response to bleeding [19, 21, 24]. This phase lasts for several minutes, mainly affects the epithelial and endothelial compartments, as well as blood cells. The main processes are as follows: formation of a fibrin clot and hemostasis that are provided by external and internal cascades of coagulation, cause vascular spasm, adhesion, and platelet aggregation. This releases growth factors and vasoactive molecular substances that trigger the migration of immunocompetent cells to the wound [22, 31, 32].

Simultaneously with the hemostasis activation, the inflammatory phase is induced (from a few minutes to 1-2 days, sometimes up to 2-3 weeks), which includes vascular and cellular responses [33, 34]. Clinically, inflammation is manifested as tissue edema, infiltration, and activation of macrophages (monocytes) and neutrophils. This phase includes sanitation of necrotic tissues, phagocytosis of bacteria, vascular responses (initial pronounced vasoconstriction replaced by intense vasodilation and increased capillary permeability), and secretion of regulatory mediators that initiate the formation of granulation tissue [29, 33, 35-37].

Furthermore, the inflammatory phase is accompanied by activation of fibronectin synthesis induced by growth factors, as well as by migration of fibroblasts - pluripotent stromal cells that dominate cell populations on the first day and play a significant role in healing - towards the wound $[11,30,33]$. During this period, a large number of mediators are released into the wound, thus, providing the process of granulation formation, including proangiogenic growth factors that initiate the proliferation and organization of vascular endothelial cells [27, 29, 34, 35].

The following phase, proliferation, begins at $12 \mathrm{~h}$ post-injury and involves a number of important processes. This period is characterized by the migration and proliferation of keratinocytes which are the main epidermis cells, the rapid division of fibroblasts and secretion of type I and III collagen by them (up to a normal ratio of $4: 1$ ), and the formation of extracellular matrix that increases the strength of wound [36, 37].

On days 10-14 post-injury, the tissue remodeling phase begins. During this phase, the synthesis and lysis of collagen comes to equilibrium, excessive macromolecules degrade, and the cellular phenotypes and the integrity of the skin restore [11, 31, 38-40]. The criterion for successful wound treatment is the epithelialization of the wound surface, which depends on angiogenesis 
occurring through migration, proliferation, and organization of vascular endothelial cells, as well as the functional and anatomical restoration of the skin with no visible scar mark [30, 41-43].

Depending on the duration and pattern of the healing process, acute and chronic wounds are distinguished. An acute wound appears as a result of traumatic or operational (surgical) damage to the skin and heals within 8-12 weeks, depending on the size and degree of tissue injury [23, 24, 44, 45]. Duration of the phases and sequence of the healing stages can be disturbed by a number of local and systemic factors (blood pressure, the presence of diabetes mellitus, hypoxia, necrosis, excessive accumulation of reactive oxygen species). A long-lasting and incomplete healing process causes chronic, recurrent, or long-term non-healing wounds (from 12 weeks or more), which often do not reach functional and anatomical recovery even after a long-term treatment $[5,12,40,46]$.

The major objective of treatment of skin injuries is to select the proper wound dressing in order to create optimal conditions for accelerating the healing of injuries and minimizing the risk of possible complications: infection, formation of resident cell phenotypes, matrix degradation, etc. $[24,31,34,47-50]$.

\section{Classification of wound dressings}

Since ancient times, linen and cotton bands, down, boiled wool, woven and non-woven fabrics with various degrees of hygroscopicity, impregnated with oil, honey, resin or wine have been used as bandage materials $[1,4,6]$. Their main function was to protect wounds from environmental factors, absorb wound exudate, and prevent secondary infection [43, 47, 51]. The discovery of the antiseptic properties of phenol, silver nitrate, zinc sulfate, wine and camphor alcohols, as well as impregnation of bandage with them, became an important milestone in wound treatment approaches in the 19th century. The subsequent advent of antibiotics, along with the invention of the occlusive dressing, led to a revolution in wound treatment techniques and a sharp reduction in mortality $[6,52]$.

Traditional sterile cotton gauze (tulle) bandages were used for many decades, until in the 1950s their list was extended with synthetic materials made of polymers (nylon, polyethylene, polypropylene, polyesters, etc.), which, according to modern classification, belong to passive (inert) wound dressings $[32,53,54]$. In the same period, there was a radical change in views on the wound dressing, the main function of which is the treatment of wounds, and not just covering it $[53,54]$.

Modern classifications include wound dressings constructed from natural and synthetic polymers. They are grouped as passive, interactive (semi-occlusal, occlusal and nanocomposite), including those containing natural biologically active substances. Interactive dressings are 
available in the form of films, foams, hydrogels (hydro-fibers) and hydrocolloids [6]. The subject of this review is nanocomposite dressings based on marine biopolymers (Fig. 2).

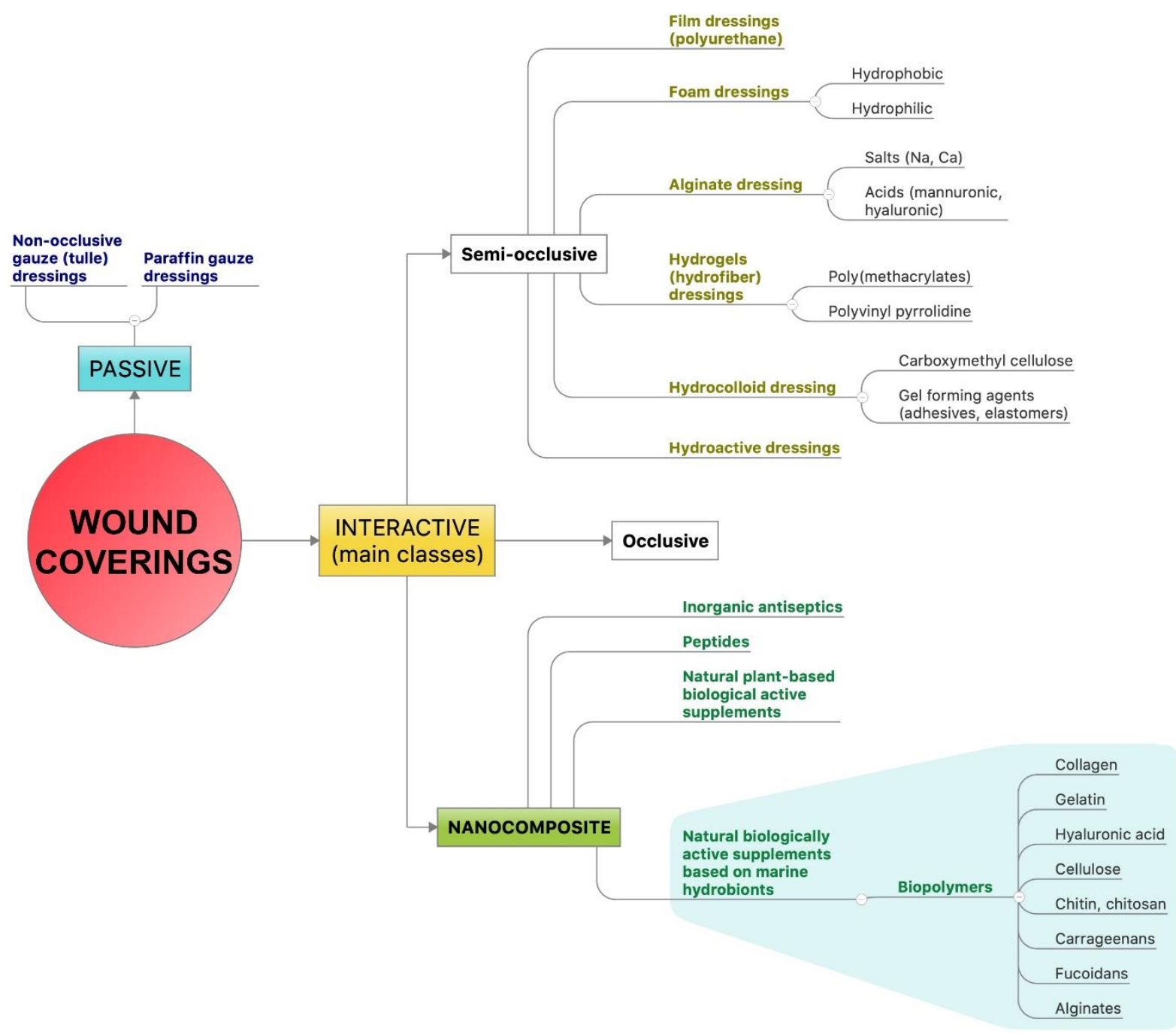

Fig. 2. Modern classifications include wound coverings constructed from natural and synthetic polymers. They are grouped as passive, interactive (semi-occlusal, occlusal and nanocomposite), including those containing natural biologically active substances.

Currently, these coatings have not lost their relevance and are used with some limitations as primary or secondary bandages for exudate removal and wound treatment. In addition, traditional materials provide certain antibacterial protection, are passively involved in wound healing, but can damage young epithelial cells during re-bandages, and require frequent changes to prevent maceration of healthy tissues [6,53-55]. Among the earliest modern modifications of this type of dressing are paraffin bandages that do not injure tissues when removed. They are used for first- or second-degree burns and as skin grafts [6, 39, 56, 57].

Until the middle of the 20th century, the generally accepted condition for successful treatment was keeping wound dry. However, in the 1960s, the results of research by G.D. Winter (1962) [58], and by C.D. Hinman and H. Maibach (1963) [59] were published in Nature. They 
showed that maintaining a moist environment in wounds provides a better effect of detritus purification without damaging cells, accelerates the formation of the vascular network, and increases the epithelialization rate by almost $50 \%[42,60]$. The wound fluid is necessary for the normal functions of macrophages, neutrophils, keratinocytes, and fibroblasts. Furthermore, it contains proteolytic enzymes and growth factors involved in the wound healing phases [51, 60, 61].

To date, there are more than 500 known wound dressing types differing in composition and properties that are used in clinical practice $[6,62]$. The introduction of a new type of wound dressings - interactive dressings that control the microenvironment and moisture balance in the wound - in recent decades was the result of increased requirements to the treatment of skin injuries $[6,52,63,64]$.

Modern wound dressings not only should be non-toxic, non-allergenic, biocompatible, biodegradable, and mechanically strong, but also possess bioactivity: they should release included biomolecules into the wound area and play the role of a medicinal form in the healing process [52, 53, 65]. Furthermore, they should have a complex therapeutic effect: create and maintain an optimal environment for healing on the wound surface with a balanced level of moisture and irreversible binding of wound exudate, provide gas exchange, and maintain appropriate temperature in tissues, have antibacterial and antioxidant properties, stimulate cell migration, and provide non-traumatic removal after healing [6, 53, 66-68].

However, there is not a single type of dressing that is universal and suitable for all types of wounds. In addition, in the process of healing in the wound, changes occur that require the use of wound dressings with other properties and methods of immobilization [42, 68].

Since the early 21 st century, there has been a steady increase in production of commercial wound dressings that meet these requirements to certain extent (hydrogels, hydrocolloids, sponges, films, and foams), as well as innovative dressing types. Effectiveness of modern interactive dressings (made of both natural and synthetic polymers) significantly increases when the basic structural material is impregnated with inorganic or organic antiseptics, growth factors, and biologically active substances obtained from various sources including seaweeds (nanocomposite dressings) [42, 51].

Due to the clinical application of nanocomposite wound dressings, the paradigm of wound management based on the TIME concept (Tissue, Inflammation/Infection, Moisture and Edge) has emerged in recent decades. It includes wound tissue sanitation, elimination of inflammation/infection, maintaining of moisture balance, cleansing, and marginal epithelialization of wound [65-67].

The modern TIME concept is a basis for effective treatment and care of wounds. Therefore, the main characteristics of innovative bandages are associated with the development of composite 
(nanocomposite) structures made of natural biopolymers. These classes of wound dressings control the main healing processes by releasing active bioagents from polymer matrices into the wound: they induce thrombosis, inhibit inflammation, stimulate the migration of fibroblasts and immunocompetent cells, activate the expression of adhesion and collagen molecules, optimize regeneration, etc. [6, 52, 53, 69-72].

In modern bandage materials, marine-, plant-, animal-, fungus-derived, or bacterial polysaccharides are used as passive natural polymer matrices. Such remarkable characteristics and unique properties as high biocompatibility, mechanical strength, flexibility, porosity, and biodegradability make natural polymers a very promising material as a framework for wound dressings [69-71, 73-76].

A few detailed reviews considering the clinical practice and current biotechnological trends, as regards the design features, properties, mechanisms of action, and indications for the use of the main classes of wound dressings made of natural biopolymers, have been published in the dedicated Russian and world's literature in recent years [3, 4, 12, 31].

In accordance with the goal of the present review, we focus on modern technologies for creating polymer dressings that include biologically active compounds from marine organisms, with the emphasis on algae-derived polysaccharides and their therapeutic effect on the phases of wound healing.

\section{Biologically active compounds from marine organisms}

Natural products have always played a significant role in human life. They were consumed as food and applied as medicinal raw materials. For quite a long time, terrestrial plants, animals, and microorganisms were considered the main biological source of natural products [18,20]. With the active exploration of the marine environment, their list was extended with various marine organisms which have significant taxonomic differences from terrestrial plants, animals, and microorganisms [18, 60, 68, 76, 77].

The complexity and biodiversity of marine ecosystems is associated with the extreme conditions in the world's oceans which contribute to the synthesis of a wide and diverse range of natural products with unique structures $[15,18,20,30]$. Due to their diverse biological properties, they have become a valuable and unique technological raw material for creating commercial products highly demanded in the biomedicine market, not only as a matrix, but also as therapeutic components of wound dressings $[2,5,76]$.

In the last 60-70 years, several thousand biopolymers with a unique chemical structure were isolated and characterized from marine organisms. Most of them in many respects' superior to the known natural substances obtained from terrestrial organisms in their biological and pharmacological activity $[2,14-18,44,45,53,76,78]$. It is no accident the study of the possibilities 
of using marine metabolites with powerful anti-inflammatory, analgesic, antioxidant, antibacterial and procoagulant activity for medical purposes attracts the attention of physicians, biologists, chemists and biotechnologists $[14,20,60,61]$. This is due to their huge biotechnological potential for the development of modern nanocomposite wound dressings [14, 55, 59, 68].

In recent decades, a significant number of experimental and clinical studies have been conducted to clarify the ability of marine biopolymers (alginates, ulvans, chitosan, chitin, carrageenans, fucoidans, etc.) to modulate certain phases of the wound healing process $[2,16,19$, 20, 30, 44-46, 48]. The significant potential to influence the focus of injury by inhibiting inflammation, activating fibroblast proliferation, and remodeling tissues has been revealed. This influence is mediated by a variety of associated mechanisms that have a synergistic action on the overall effectiveness of local treatment, which proved to be especially pronounced in case of using polysaccharides from seaweed [2, 19, 53, 55, 59, 79-81].

\section{Polysaccharides from marine algae used in the development of wound dressings}

Marine algae are among the most ancient inhabitants of the planet. These are photosynthetic organisms with complex and peculiar taxonomy [18, 19, 20, 42]. Currently, two main types of algae are distinguished: microalgae, consisting of one eukaryotic cell, and widely represented in marine ecosystems as plankton, and a heterogeneous group of macroalgae, occupying the littoral zone and having large sizes $[55,56,59,70]$.

Over millions of years of existence in the marine ecosystem, they have developed effective mechanisms of antibiotic protection against pathogenic microorganisms and numerous strategies of survival under extreme abiotic conditions of the environment [2, 10, 21, 44-49]. During evolution, these organisms acquired the ability to synthesize a wide range of metabolites and biomolecules, many of which have a unique chemical structure that other organisms do not have [10, 53-56, 76, 77]. Polysaccharides from marine algae are of particular interest due to the high resistance, biological activity, and availability of these organisms in large numbers [21, 59, 61, 69, 74].

Wide interest in the cultivation of marine macroalgae, the subsequent extraction of polysaccharides and their use for various purposes arose many years ago, including for therapeutic use, taking into account their antiviral, antibacterial, immunomodulating and antitumor activity $[19,55,59,61]$.

The unique healing properties of algae for wound treatment have been known for many centuries. For these properties, sailors called them "mariner's cures" [79]. Over the past decades, rich experience has been accumulated in the use of numerous homo- and heteropolysaccharides, widely represented in the main classes of marine algae, as a therapeutic basis for wound dressings [14-17, 47]. In recent years, these biopolymers consisting of monosaccharides linked by glycosidic bonds have attracted increasing attention as biotechnological raw materials for pharmacology, food and cosmetic additives $[14,15]$. 
The increased technological opportunities for isolation and purification of these polysaccharides have substantially expanded the range of their practical and potential application as a basis for various types of wound dressings [2, 48, 49, 53, 56, 75]. Due to their chemical and physical characteristics, such as mechanical strength, emulsification, adhesive properties, the ability to form hydrocolloids, non-toxicity, they have a more pronounced healing effect compared to their traditional natural counterparts $[49,53,56]$.

In recent decades, hydrogels - three-dimensional hydrophilic polymer chains consisting of 99\% water have become an example of the widespread use of algae polysaccharides in the design of wound dressings and tissue engineering [70, 74]. Due to the high biocompatibility, low immunogenicity and cytotoxicity, as well as the ease of functioning in our time, these polymer systems are actively used for wound healing [10, 21, 44, 54, 69, 70-72].

The 3D reticulate structure of hydrogels simulates the microarchitectonics of extracellular matrix of native tissue, acts as a physical barrier against bacteria, providing optimal conditions in vivo for cell survival $[21,45,55,61]$. In addition, the attractiveness of using polysaccharides from algae for the creation of hydrogels is related to their biological activity, biocompatibility and biodegradability, as well as the possibility of physicochemical modification of the structure $[2,10,69,76,77]$.

The structural attractiveness of this type of wound dressings is enhanced by including nanofillers with antimicrobial and anti-inflammatory activity (gold, silver, zinc and copper oxides, antibiotics, hormones, etc.) in their composition [2, 21, 44, 55, 69].

Biocompatibility and biodegradability are particularly attractive characteristics of algaederived polysaccharides, due to which they can simulate the extracellular matrix to a certain extent $[2,48,75]$. These properties have raised significant biotechnological interest in these biopolymers used as a therapeutic basis for designing bandage materials for already several decades [2, 46, 47, $55,56]$.

In particular, a significant therapeutic potential was revealed in classes of various polysaccharides, the main components of algae (fucoidans, alginates, carrageenans, ulvans, cellulose, and laminarins) in which they perform important structural functions [10, 21, 48]. Their content in algae has seasonal and species-species variations, and their constant trait - high hydrophilicity - fully fits the modern concept of creating moist conditions for wound treatment $[48,49]$. This feature of algae polysaccharides makes them direct participants in the wound healing process and an indispensable natural biomaterial for the construction of various types of modern wound dressings. [48, 74, 77].

Below is a more detailed consideration of the best-known polysaccharides that are already widely applied or promising components of wound dressings with proven effectiveness and high potential for wound healing. 


\section{Alginates}

One of the most common marine biopolymers in the world are alginates - polysaccharides of brown algae (Fucus taxon). They have long been effectively used as a gelling agent and stabilizer of various solutions and suspensions, as well as valuable components in food, chemical, and biotechnological production. These polysaccharides are an indispensable component of various products manufactured in the pharmaceutical and medical industry [77, 79, 80]. The unique characteristics of these metabolites have found application as a therapeutic basis for nanocomposite wound dressings [78, 80, 81].

The physicochemical properties of these linear acidic polysaccharides depend on the structural relationship of the two types of uronic acids, L-guluronic (G) and D-mannuronic (M), located in biomolecule in the form of homo- or heteropolymer blocks (Fig. 3-A).

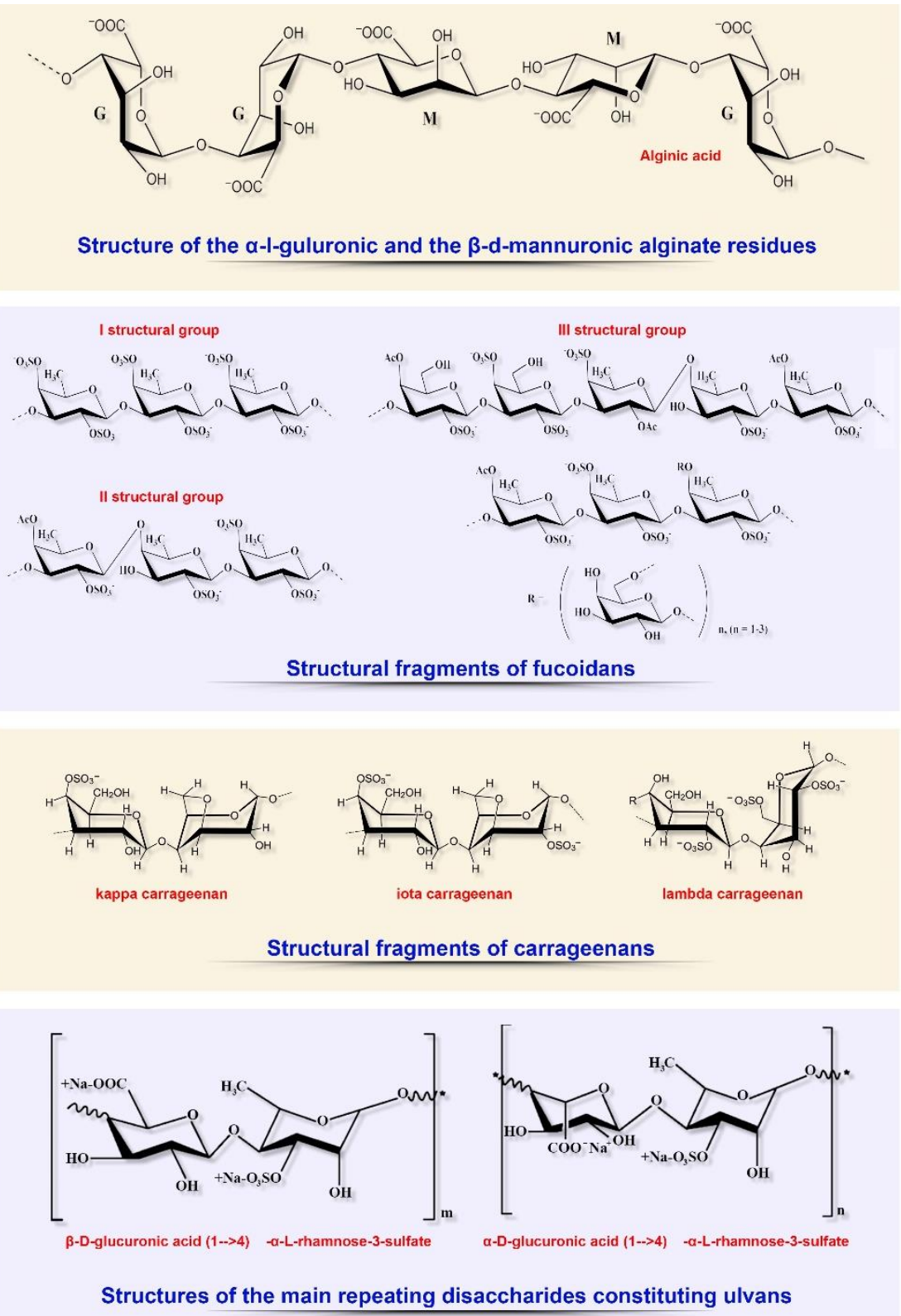

Fig. 3. Structural diversity of algal sulfated polysaccharides: $\alpha$-I-guluronic and $\beta$-d-mannuronic alginate residues (A); fragments of fucoidans (B); fragments of carrageenans (C); main repeating disaccharides constituting ulvans (D). 
The most common technology for obtaining hydrogels from aqueous alginate solution is combination with an ionic crosslinking agent that is divalent cations (e.g., $\mathrm{Ca}^{2+}, \mathrm{Ba}^{2+}$, or $\mathrm{Co}^{2+}$ ) interacting with G-fragments of polymer chains [80]. Constructed calcium-alginate wound dressings with a high content of G-blocks have a lower rate of ion $(\mathrm{Ca}-\mathrm{Na})$ exchange with exudate, slowly swell, but are removed atraumatically and painlessly during dressings [82, 83].

Analogous dressings, but with a high content of M-blocks, quickly absorb wound exudate, but require special irrigation when removed [82-84]. The ability of sodium ions to form transverse bonds with alginate makes these porous coatings almost ideal barrier membranes for tissue engineering and targeted tissue regeneration [23, 25, 29, 85].

In recent reviews, the features of structure and chemical properties of alginates and variants of their use in modern medicine have been considered more in detail $[25,86]$.

When modern interactive nanocomposite wound dressings are created, the most valuable biological and pharmacological characteristics of these natural polyelectrolyte biopolymers include the biocompatibility, non-toxicity, biodegradability, as well as high hemostatic activity associated with the release of calcium ions which activate platelets and other clotting factors $[79,80,87,88]$. The potent procoagulant properties of these anionic biopolymers were proposed to be used in the composition of calcium-sodium gel dressings for healing various types of wounds already in the second half of the $20^{\text {th }}$ century (Kaltostat ${ }^{\mathrm{TM}}$, Kaltocarb $^{\mathrm{TM}}$, Kaltoclud $\left.{ }^{\mathrm{TM}}\right)$ [79].

At the same time, it was found that alginates included in wound dressings, in addition to the high hemostatic activity, provide the optimum moist environment in the wound and good absorption of wound exudate (20-fold relative to the dressing weight), stimulate the growth of granulation tissue, reduce the concentration of pro-inflammatory cytokines, inhibit the formation of free radicals, and have a pronounced antimicrobial activity [80, 87, 89]. Clinically, this is manifested as a reduction in the healing time and longer intervals between bandagings, which also become painless and atraumatic $[80,87,88,90]$.

Due to their other, but no less important biotechnological properties (such as low cost, availability, and high biocompatibility), alginates are widely used in modern commercial hydrogel wound dressings in combination with metal ions for the treatment of acute and chronic wounds: diabetic ulcers, bedsores, and traumatic and surgical wounds (Algicell ${ }^{\mathrm{TM}}$, AlgiSite ${ }^{\mathrm{TM}} \mathrm{M}, \mathrm{Comfeel}^{\mathrm{TM}}$ Plus, etc.) [88, 91-94].

Furthermore, film and foam dressings based on sodium alginate also seem to be very promising. These types of wound dressings improve wound healing by normalizing gas exchange, 
protecting wounds from infection, especially in combination with other biopolymers, essential oils, or surfactants that enhance dispersion $[89,92,93]$.

The modern world pharmaceutical market offers a great variety of different types of alginate-based bandages, from traditional hydrogel dressings to innovative lyophilized sheets and nanofibers for cavity wounds [27, 46, 95-97], as well as combined designs of these polysaccharides with $\mathrm{Zn}, \mathrm{Mn}, \mathrm{Ag}$, glycerol, polyvinyl alcohol, and other marine-derived polymers [94, 98-100].

For example, K. Murakami with co-authors [87] managed to effectively implement the wound healing properties of alginates in combination with other marine BAS (fucoidan, chitin/chitosan) and mitomycin $\mathrm{C}$ in a design of hydrogel-based wound dressing [87]. The results of experimental studies have shown that this combination of marine biopolymers has a large number of properties of perfect dressing for wound healing: chemoatractive effect on fibroblasts, activation of their proliferation, as well as acceleration of tissue re-epithelialization and granulation, which began to appear on day 7 [87].

In analysis of the mechanisms of healing action of this wound dressing, attention is drawn, first, to the effective combined action of brown algae polysaccharides: alginates and fucoidans, whose low mechanical strength in this case is compensated by chitin and chitosan $[95,101,102]$.

Recently, polysaccharide-containing hydrogel bifunctional platforms based on a combination of alginate and hyaluronic acid, which are successfully used in cosmetology [23, 29, $80,101,102$,], with hyaluronan, its derivative, have shown themselves well in wound healing. As it turned out, hyaluronan decelerates the release of $\mathrm{Ca}^{2+}$ ions, regulates the alginate gelation, and, at the initial stages of healing, provides wound moisturization, activates migration and proliferation of keratinocytes [85, 101, 102-104].

Thus, with the overall biological efficiency of alginate-containing hydrogel monoplatforms, the gelation process is a difficult-to-control stage, which results in heterogeneity of the gel structure and its unsatisfactory mechanical strength [101, 105]. In an experimental model, gel-like mixtures based on the alginate-hyaluronic acid combination showed a more rapid wound healing effect due to a positive influence on the gelation kinetics $[101,102,106]$. In addition, alginate-hyaluronan hydrogel structures exhibit the potential to be used as a platform for delivering biologically active compounds directly into the wound [102, 107].

Thus, alginates have long and firmly been recognized a therapeutic basis in numerous and diverse designs of modern commercial wound dressings (Table). The high biocompatibility, sorption properties, and ease of gelation have provided the widest distribution of these biopolymers in biomedical science, biotechnology, and tissue engineering. 
Examples of commercially available alginate wound dressings based on seaweed polysaccharides

\begin{tabular}{|c|c|c|c|c|}
\hline Commercial name & Feature & Benefits & Indications for use & Links \\
\hline $\begin{array}{l}\text { AlgiCell }{ }^{\circledR} \mathrm{Ag} \\
\text { (Integra } \\
\text { LifeSciences } \\
\text { Corp.) }\end{array}$ & $\begin{array}{l}\text { Antimicrobial gel high-strength } \\
\text { calcium-alginate dressing with } \\
\text { complex silver ion transfer } \\
\text { technology }(1.4 \%)\end{array}$ & $\begin{array}{l}\text { - Consists of a patented mixture of D-mannuronic } \\
\text { and L-guluronic acids, which provides good } \\
\text { gelation and high moisture resistance. } \\
\text { - High absorption capacity } \\
\text { - Removing the dressing does not leave any } \\
\text { residue of silver coated nylon thread in the wound }\end{array}$ & $\begin{array}{l}\text { It is the main dressing for wounds with } \\
\text { moderate to profuse exudate (pressure sores, } \\
\text { diabetic ulcers, postoperative wounds, leg } \\
\text { ulcers, donor sites, lacerations and } \\
\text { abrasions). Treatment of infected wounds. }\end{array}$ & $\begin{array}{l}{[23,29,} \\
81,108, \\
109]\end{array}$ \\
\hline $\begin{array}{l}\text { Derma AlgiCell }{ }^{\circledR} \\
\text { (Integra } \\
\text { LifeSciences } \\
\text { Corp.) }\end{array}$ & $\begin{array}{l}\text { This is a soft, sterile calcium } \\
\text { alginate dressing. Consists of a } \\
\text { mixture of D-mannuronic and } \\
\text { L-guluronic acids. }\end{array}$ & $\begin{array}{l}\text { - absorbs from moderate to a large amount of } \\
\text { exudate. Covers or fills the wound cavity. } \\
\text { - Easily and painlessly removed during dressings. } \\
\text { - Maintains a moist wound environment. }\end{array}$ & $\begin{array}{l}\text { It is used for topical treatment of wounds } \\
\text { with moderate to profuse exudate (pressure } \\
\text { sores, diabetic ulcers, postoperative wounds, } \\
\text { leg ulcers, lacerations and abrasions). }\end{array}$ & $\begin{array}{c}{[86,89,} \\
108]\end{array}$ \\
\hline $\begin{array}{l}\text { AlgiCell } \\
\text { (Integra } \\
\text { LifeSciences } \\
\text { Corp.) }\end{array}$ & $\begin{array}{l}\text { Nonwoven wound dressings, } \\
\text { dressings, or fibers. }\end{array}$ & $\begin{array}{l}\text { Upon contact with exudate, these dressings form a } \\
\text { wet gel during ion exchange. } \\
\text { - High gel strength, painless and atraumatic } \\
\text { removal from the wound. } \\
\text { - Well maintains moisture in the wound. }\end{array}$ & $\begin{array}{l}\text { Diabetic or venous ulcers, infected wounds. } \\
\text { Can be used in the form of a rope to plug } \\
\text { deep wounds or to stop minor bleeding. }\end{array}$ & $\begin{array}{c}{[94,99} \\
108]\end{array}$ \\
\hline $\begin{array}{l}\text { AlgiSite }{ }^{\circledR} \mathrm{M} \\
\text { (Smith and } \\
\text { Nephew, Inc.) }\end{array}$ & $\begin{array}{l}\text { alginate dressing containing } \\
\text { cium forms a hydrophilic gel } \\
\text { on contact with exudate. }\end{array}$ & $\begin{array}{l}\text { - Helps prevent scab formation and helps reduce } \\
\text { wounds. Easy painless removal when changing. } \\
\text { - Optimizes gas exchange in the wound bed. }\end{array}$ & $\begin{array}{l}\text { Torn wounds, abrasions, cuts of the skin, } \\
\text { minor burns, diabetic, bedsores or vascular } \\
\text { ulcers and surgical wounds. }\end{array}$ & $\begin{array}{c}{[82,94} \\
106,110]\end{array}$ \\
\hline $\begin{array}{l}\text { Amerx }{ }^{\circledR} \\
\text { (Amerx Health } \\
\text { Care Corp.) }\end{array}$ & $\begin{array}{l}\text { ressings in the form of a } \\
\text { erile, elastic pad containing } \\
\text { lcium. }\end{array}$ & $\begin{array}{l}\text { - High absorbency, quickly forms a hyd } \\
\text { gel to create and maintain optimal moist } \\
\text { wound. Convenient packaging, easy to } ~\end{array}$ & $\begin{array}{l}\text { Designed for use as primary dressings for } \\
\text { exudative chronic and acute wounds with } \\
\text { tearing and crushing of the skin. }\end{array}$ & {$[84,111]$} \\
\hline $\begin{array}{l}\text { Biatain }{ }^{\circledR} \text { Alginate } \\
\text { (Coloplast Corp.) }\end{array}$ & $\begin{array}{l}\text { High-performance alginate } \\
\text { dressings with high absorbent } \\
\text { properties. }\end{array}$ & $\begin{array}{l}\text { - Available in waterproof format. } \\
\text { - It has hemostatic properties. } \\
\text { - High biocompatibility. } \\
\text { - Optimal drainage of wound exudate. }\end{array}$ & $\begin{array}{l}\text { Diabetic or venous ulcers. All types of acute } \\
\text { or chronic wounds, accompanied by minor } \\
\text { bleeding. }\end{array}$ & $\begin{array}{l}{[80,93,} \\
112]\end{array}$ \\
\hline $\begin{array}{l}\text { Cuticerin }{ }^{\mathrm{TM}} \text { Gauze } \\
\text { Dressings } \\
\text { (Smith and } \\
\text { Nephew, Inc.) }\end{array}$ & $\begin{array}{l}\text { Alginate mesh dressing soaked } \\
\text { in neutral hydrophobic euserin } \\
\text { ointment, petroleum jelly, } \\
\text { paraffin. }\end{array}$ & $\begin{array}{l}\text { - Impregnated soft acetate fibers reduce the risk of } \\
\text { granulation tissue growing through the dressing. }\end{array}$ & $\begin{array}{l}\text { Для лечения ожогов, обширных ссадин и } \\
\text { других экссудирующих ран с дефектами } \\
\text { кожи. Используется при местном лечении } \\
\text { лучевых повреждений кожи. }\end{array}$ & $\begin{array}{l}{[20,94,} \\
108]\end{array}$ \\
\hline $\begin{array}{l}\text { CarboFLEX } \\
\text { (ConvaTec) }\end{array}$ & $\begin{array}{l}\text { Hydrocolloid, sterile, non- } \\
\text { adhesive, five-layer dressing for } \\
\text { direct contact with the wound, } \\
\text { absorption of odors. }\end{array}$ & $\begin{array}{l}\text { - Specially designed to solve control problems } \\
\text { associated with unpleasant odors on the wound. }\end{array}$ & $\begin{array}{l}\text { When treating infected, foul-smelling } \\
\text { wounds with a normal or significant amount } \\
\text { of wound exudate. }\end{array}$ & {$[20,88]$} \\
\hline
\end{tabular}




\begin{tabular}{|c|c|c|c|c|}
\hline $\begin{array}{l}\text { Carbonet }^{\circledR} \\
(\text { ConvaTec) }\end{array}$ & $\begin{array}{l}\text { A multi-layered, flexible and } \\
\text { soft odor-absorbing dressing } \\
\text { that is highly adaptable to } \\
\text { wound contours }\end{array}$ & $\begin{array}{l}\text { - Specially designed to solve control problems } \\
\text { associated with unpleasant odors on the wound. } \\
\text { - Forms a soft, hydrophilic, gas-permeable gel } \\
\text { upon contact with exudate. }\end{array}$ & $\begin{array}{l}\text { When treating infected, foul-smelling } \\
\text { wounds with a normal or high amount of } \\
\text { discharge (surgical wounds, fecal fistulas, } \\
\text { venous leg ulcers, etc.) }\end{array}$ & $\begin{array}{l}{[20,42} \\
80,108]\end{array}$ \\
\hline $\begin{array}{l}\text { CovaWound }^{\mathrm{TM}} \\
\text { (Covalon }^{\text {Technologies, Ltd.) }}\end{array}$ & $\begin{array}{l}\text { A primary wound dressing made } \\
\text { from the calcium salt of alginic } \\
\text { acid rich in D-mannuronic acid. }\end{array}$ & $\begin{array}{l}\text { - The dressing follows the contours of the wound } \\
\text { and provides a microenvironment that promotes } \\
\text { wound healing. }\end{array}$ & $\begin{array}{l}\text { It can be applied to burn wounds, ulcers } \\
\text { (diabetic, vascular), strip wounds, } \\
\text { postoperative incisions, traumatic wounds, } \\
\text { sluggishly granulating wounds. }\end{array}$ & $\begin{array}{l}{[18,41} \\
42,113]\end{array}$ \\
\hline $\begin{array}{l}\text { Cutimed }{ }^{\circledR} \text { Alginate } \\
\text { (Essity) }\end{array}$ & $\begin{array}{l}\text { Hydrogel alginate dressing, has } \\
\text { a high absorbency and helps } \\
\text { maintain a moist environment in } \\
\text { the wound. }\end{array}$ & $\begin{array}{l}\text { - Maintains a moist environment in the wound } \\
\text { - Fast gelation upon contact with exudate. High } \\
\text { gel stability. Highly absorbent base provides } \\
\text { effective drainage of the wound. }\end{array}$ & $\begin{array}{l}\text { It is used to clean necrotic weakly bleeding } \\
\text { wounds and ulcers (pressure sores, trophic, } \\
\text { diabetic). }\end{array}$ & $\begin{array}{l}{[20,22,} \\
42,108]\end{array}$ \\
\hline $\begin{array}{l}\text { DermaGinate }{ }^{\mathrm{TM}} 12^{\prime} \\
\text { Rote (DermaRite } \\
\text { Industries, LLC) }\end{array}$ & $\begin{array}{l}\text { Calcium-alginate dressing that } \\
\text { easily fills the wound bed. }\end{array}$ & $\begin{array}{l}\text { - Forms a calming gel-like consistency upon } \\
\text { contact with wound exudate. } \\
\text { - Easily and painlessly removed during dressings. }\end{array}$ & $\begin{array}{l}\text { Dressing for wounds with moderate to profuse } \\
\text { exudate (pressure sores, diabetic ulcers, } \\
\text { postoperative wounds, and lacerations). }\end{array}$ & $\begin{array}{l}{[20,41,} \\
92]\end{array}$ \\
\hline $\begin{array}{l}\text { DermaGinate } / \mathrm{Ag}^{\mathrm{TM}} \\
\text { (DermaRite } \\
\text { Industries, LLC) }\end{array}$ & $\begin{array}{l}\text { Silver-alginate dressing. It limits } \\
\text { the growth of bacteria in a } \\
\text { dressing to reduce the risk of } \\
\text { secondary infection of wounds. }\end{array}$ & $\begin{array}{l}\text { - Effectively sorb from moderate to significant } \\
\text { volume of exudate. Easily fills a bed of wounds. } \\
\text { - Creates a soothing gel-like consistency upon } \\
\text { contact with exudate in the wound. } \\
\text { - Maintains moisture in wounds. }\end{array}$ & $\begin{array}{l}\text { It is intended for topical treatment of wounds } \\
\text { with moderate and severe exudation, } \\
\text { including pressure sores, diabetic ulcers, } \\
\text { postoperative wounds, traumatic wounds, leg } \\
\text { ulcers, grafts and donor skin sites. }\end{array}$ & {$[42,92]$} \\
\hline $\begin{array}{l}\text { DynaGinate } \\
\text { (DermaRite } \\
\text { Industries, LLC) }\end{array}$ & $\begin{array}{l}\text { A sterile dressing made of } \\
\text { calcium alginate, designed to } \\
\text { protect the wound and maintain } \\
\text { its moist environment. }\end{array}$ & $\begin{array}{l}\text { - It has a high absorption capacity, which is designed } \\
\text { to absorb moisture } 17 \text { times its own weight. } \\
\text { - Easily forms a gel in contact with exudate, } \\
\text { maintains wound moisture and speeds up the } \\
\text { healing process. }\end{array}$ & $\begin{array}{l}\text { The dressing is ideal for patients with diabetic } \\
\text { ulcers, leg ulcers, surgical wounds, lacerations, } \\
\text { abrasions. It does not stick to the wound bed, } \\
\text { which reduces pain and discomfort when } \\
\text { changing the bandage. }\end{array}$ & {$[42,92]$} \\
\hline $\begin{array}{l}\text { ExcelGinate } \\
\text { (MPM Medical, } \\
\text { Inc., USA) }\end{array}$ & $\begin{array}{l}\text { Primary non-woven calcium } \\
\text { alginate dressing for partial or } \\
\text { full thickness of wounds with } \\
\text { moderate or severe drainage. }\end{array}$ & $\begin{array}{l}\text { - Tightly woven, when removed, the integrity of } \\
\text { the coating is fully preserved. } \\
\text { - Highly absorbent coating properties, absorbs } \\
\text { four times its weight. } \\
\text { - Can be used on infected wounds. }\end{array}$ & $\begin{array}{l}\text { The dressing is suitable for patients with } \\
\text { moderately bleeding traumatic and surgical } \\
\text { wounds with moderate or profuse exudate, as } \\
\text { well as bacterial contamination of wounds. }\end{array}$ & $\begin{array}{l}{[20,42} \\
82,114]\end{array}$ \\
\hline $\begin{array}{l}\text { Fibracol }^{\mathrm{TM}} \text { Plus } \\
\text { (Systagenix) }\end{array}$ & $\begin{array}{l}\text { Combination dressing of } 90 \% \\
\text { collagen and } 10 \% \text { alginate. }\end{array}$ & $\begin{array}{l}\text { - Maintains integrity when wet. } \\
\text { - Does not stick when removed, does not leave } \\
\text { fibers in the wound. } \\
\text { - Alginate helps maintain a moist environment in } \\
\text { the wound, stimulates the formation of granulation } \\
\text { tissue and epithelization. }\end{array}$ & $\begin{array}{l}\text { The dressing is designed for the treatment of } \\
\text { exudative wounds, including pressure sores; } \\
\text { venous ulcers; ulcers caused by mixed } \\
\text { vascular etiology; diabetic ulcers; second } \\
\text { degree burns; donor skin. }\end{array}$ & $\begin{array}{l}{[20,42,} \\
83,115]\end{array}$ \\
\hline
\end{tabular}




\begin{tabular}{|c|c|c|c|c|}
\hline $\begin{array}{l}\text { GEMCORE } 360^{\circ} \mathrm{TM} \\
\text { (GEMCO Medical, } \\
\text { USA) }\end{array}$ & $\begin{array}{l}\text { Reinforced dressing with } \\
\text { calcium alginate in the form of } \\
\text { antimicrobial foam soaked in } \\
\text { polyhexamethylene biguanide }\end{array}$ & $\begin{array}{l}\text { - Maintains a moist wound environment. } \\
\text { - Forms a soft, flexible hydrophilic layer of gel } \\
\text { upon contact with exudate. } \\
\text { - Active against a wide range of bacteria (including } \\
\text { MRSA, MRSE, VRE, Escherichia coli, Klebsiella } \\
\text { pneumoniae, Pseudomonas aeruginosa, Candida } \\
\text { albicans и Rhodotorula mucilaginosa) }\end{array}$ & $\begin{array}{l}\text { It is indicated for the treatment of chronic } \\
\text { and acute wounds, can be used for vascular } \\
\text { and diabetic ulcers, oral wounds, } \\
\text { postoperative wounds and burns of the first } \\
\text { and second degree, can be used to treat } \\
\text { infected wounds. }\end{array}$ & $\begin{array}{l}{[20,84,} \\
116]\end{array}$ \\
\hline $\begin{array}{l}\text { Kalginate }^{\mathrm{TM}} \text { Thin } \\
\text { (DeRoyal, USA) }\end{array}$ & $\begin{array}{l}\text { Alginate primary dressing of } \\
\text { heavy fibers for adsorption of } \\
\text { exudate. }\end{array}$ & $\begin{array}{l}\text { - Absorb exudate up to } 20 \text { times its weight. } \\
\text { - Great for daily dressings. } \\
\text { - Forms a soluble sodium gel upon contact with } \\
\text { liquid contents in the wound. } \\
\text { - Available in coating or turunda options }\end{array}$ & $\begin{array}{l}\text { It can be used for: vascular or diabetic ulcers; } \\
\text { superficial wounds and burns; postoperative } \\
\text { cut wounds; infected and uninfected wounds. }\end{array}$ & $\begin{array}{l}{[49,85,} \\
117]\end{array}$ \\
\hline $\begin{array}{l}\text { KALTOSTAT }^{\circledR} \\
\text { Alginate Dressing } \\
\text { (ConvaTec, UK) }\end{array}$ & $\begin{array}{l}\text { The alginate dressing forms an } \\
\text { absorbent gel-fiber matrix in } \\
\text { contact with the liquid. }\end{array}$ & $\begin{array}{l}\text { - Supports a moist wound environment and facilitates } \\
\text { atraumatic removal. } \\
\text { - Used for infected wounds under the supervision of a } \\
\text { medical professional. }\end{array}$ & $\begin{array}{l}\text { It is shown as a wound dressing for local } \\
\text { treatment of vascular and diabetic ulcers, } \\
\text { lacerations and postoperative wounds. }\end{array}$ & $\begin{array}{l}{[21,42,} \\
79]\end{array}$ \\
\hline $\begin{array}{l}\text { KALTOSTAT }^{\circledR} \\
\text { Alginate Rope } \\
\text { (ConvaTec, UK) }\end{array}$ & $\begin{array}{l}\text { Forms an absorbing matrix of } \\
\text { gel fiber in contact with wound } \\
\text { fluid }\end{array}$ & - Can be used for tamponade with nosebleeds. & $\begin{array}{l}\text { It is shown as a wound dressing for local } \\
\text { treatment of strip wounds, vascular and } \\
\text { diabetic ulcers, and postoperative wounds. }\end{array}$ & $\begin{array}{l}{[21,42,} \\
79]\end{array}$ \\
\hline $\begin{array}{l}3 \mathrm{M}^{\mathrm{TM}} \text { Tegaderm }{ }^{\mathrm{TM}} \\
\text { High Integrity } \\
(3 \mathrm{M}+\text { KCI, USA })\end{array}$ & $\begin{array}{l}\text { Highly resistant alginate coating } \\
\text { containing adsorbent }\end{array}$ & $\begin{array}{l}\text { - Provides highly stable gelation and optimal wet } \\
\text { environment. Compatible with } 3 \mathrm{M} \text { dressings. } \\
\text { - Increased absorbent properties of the dressing } \\
\text { - High comfort for the patient during dressings. }\end{array}$ & $\begin{array}{l}\text { Pressure ulcers, vascular and diabetic ulcers; } \\
\text { superficial wounds, cuts and abrasions; } \\
\text { postoperative and traumatic wounds; } \\
\text { shallow, moist exudating wounds. }\end{array}$ & $\begin{array}{l}{[80,118,} \\
119]\end{array}$ \\
\hline $\begin{array}{l}3 \mathrm{M}^{\mathrm{TM}} \text { Tegaderm }{ }^{\mathrm{TM}} \\
\text { High Integrity } \\
(3 \mathrm{M}+\mathrm{KCI}, \mathrm{USA})\end{array}$ & Provides good gelation & $\begin{array}{l}\text { - Forms a mechanically strong gel, plugging the } \\
\text { entire cavity of the wound. } \\
\text { - High comfort for the patient during dressings. } \\
\text { - Compatible with } 3 \mathrm{M} \text { dressings. }\end{array}$ & $\begin{array}{l}\text { Pressure ulcers, vascular and diabetic ulcers; } \\
\text { superficial wounds such as cuts and } \\
\text { abrasions; postoperative and traumatic } \\
\text { wounds; shallow, moist exudating wounds. }\end{array}$ & $\begin{array}{l}{[80,118,} \\
119]\end{array}$ \\
\hline
\end{tabular}


However, the resource of raw materials from marine brown algae for modern biotechnologies and creation of wound dressings is not limited to these polymers.

\section{Fucoidans}

Since the late 20th century, the number of scientific studies aimed at elucidating the therapeutic potential of other biopolymers from brown algae such as, in particular, fucoidans for the treatment of various diseases, including the opportunity to use the wide range of their biological properties for wound healing, has shown a tendency to increase (Fig. 3-B) [76, 87, 120-125].

It has been established that this class of anionic sulfated heteropolysaccharides is present only in brown algae. In addition, some marine invertebrate organisms (sea urchins, trepangs) synthesize similar polysaccharides $[15,17]$. Their structure is built only from the remains of sulfated fucose and is regular, which significantly distinguishes them from fucoidans [16, 17]. The chemical composition, structure, and biological properties of fucoidans are strongly dependent on the environmental conditions, season of collection, species of algae, as well as on the technologies for their fractional extraction and purification [69, 74, 121, 122, 124].

Different proportions of the structural monosaccharides, forming part of fucoidans, such as fucose (the main monomer), glucose, galactose (sometimes it is also the main monomer), xylose, mannose, as well as sulfate ester and uronic acid, determine biological activities of these biopolymers $[69,87,125]$. There are widely known commercial make-up products based on highly purified fucoidan extract $\left(\right.$ Maritech $^{\circledR}$ Reverse и Vita-Bright ${ }^{\mathrm{TM}}$ ) which exhibits pronounced regenerating, protective, and anti-aging properties for skin. However, in recent decades, a significant interest of biotechnologists has been the ability of fucoidans to modulate certain phases of wound healing by activating biomolecules and cellular processes [122, 123, 124].

For example, the presence and position of sulfate groups are important factors that determine the anti-inflammatory properties of these biopolymers, including the inhibitory activity of cell proliferation, peroxidation, and neutrophil migration, and also their properties as agents of the cell-receptor interaction and potent anticoagulants $[69,122,124,125]$. By the mechanism of anticoagulant action, low molecular weight fucoidans resemble heparin, they are a powerful inducer of the production of multifunctional hepatocyte growth factor (of cytokine HGF / SF), which plays an important role in the process of wound healing and re-epithelialization, stimulation of angiogenesis, and migration and proliferation of keratinocytes [126, 127].

As R. O'Leary with co-authors showed in their research [128], besides the abovementioned $\mathrm{HGF} / \mathrm{SF}$, some varieties of these polysaccharides derived from brown algae of the genus Fucus actively interact with the transforming growth factor TGF- $\beta$, which is a potent cytokine regulating cell proliferation, differentiation, apoptosis, immune response, and remodeling of the extracellular matrix [128]. In an experimental model of acute puncture wounds, the level of 
the TGF- $\beta$ factor increased rapidly, which caused scars to form at the healing site. Fucoidans inhibited the antiproliferative effect of TGF- $\beta$, significantly increased the rate of fibroblasts' repopulation of the wound and the rate of formation of the fibrillar collagen matrix, thus, being promoters of wound healing [128].

M. Kordjazi with co-authors [69] were among the first to study the wound-healing effects of fucoidans in a burn wound experiment [69]. The researchers paid attention to the anticoagulant, antithrombotic, anti-inflammatory, and antioxidant properties of these polysaccharides, whose activity depended on the degree of sulfation (from 32.6 to 19.0\%). With a higher sulfate content, the wound-healing properties of fucoidans were more pronounced, which was manifested as the degree of activation of fibroblast proliferation (which is recognized the main mechanism), collagen deposition, and an increase in the epidermis thickness [69].

Analogous studies conducted later confirmed these results. It was concluded that low molecular weight fucoidans with an increased content of sulfates and fucose accelerate the healing of skin wounds by means of a complex and coordinated antioxidant, anti-inflammatory and dependent on numerous growth factors activity [20, 120, 124 129].

The high potential of using fucoidans as the basis to create wound dressings was shown in the research of Australian scientists who used fucoidan extracted from the alga Fucus vesiculosus to design a special polyelectrolyte multilayer assembly in combination with chitosan. According to the authors, the results obtained can contribute to the invention of promising dressing materials [125].

In their recent studies, J. Cashman and A. Charboneau with co-authors revealed a high potential of fucoidans in inhibiting the formation of post-operative adhesions in abdominal wounds $[129,130]$. The authors used film-based wound dressings and preparations containing fucoidans derived from $F$. vesiculosus in experimental studies using rabbit and rat models [128].

According to medical reports, the potential and significance of the identified properties of these polysaccharides are determined by the high frequency (65-95\%) of adhesions formed after surgical operations in the abdominal and pelvic regions [63]. Therefore, the prevention and treatment of adhesion process is a public healthcare issue, since the search for barrier methods preventing adhesions has not been successful for many years [63, 129].

Nevertheless, the pathogenetic process of adhesion formation is quite well studied. The main mechanism of the adhesive process was found to be associated with the adhesion activation through the local inflammatory process mediated by a surgical damage to the peritoneum, and the subsequent exudation of plasma rich in fibrin into the cavity [63, 129].

The major, fundamental conclusion made by the authors based on the results of the experiments is that, among the numerous substances tested, fucoidans proved to be the most effective anti-adhesive, non-toxic agents, and were considered a promising candidate for clinical 
use $[129,131]$. Therefore, implementation of the high potential of using these polysaccharides in the form of hydrogels, films, and solutions for the prevention of adhesive process is highly probable in the coming years $[129,130]$.

It should be recognized that, despite the experimentally proven wide range of biological properties of fucoidans, the practical application of the wound healing properties of these polysaccharides in the form of wound dressings is still under development $[132,133]$. To date, none of the fucoidans-based products has received official approval for clinical use, despite years of efforts to purify them and study their biological activity [131, 134]. However, the results obtained give hope that it may possibly happen in the coming years.

\section{Carrageenans}

Over the past decades, the activity of studying structurally diverse metabolites from the red algae Rhodophyta with interesting biological activity has increased significantly [20, 135-137]. These algae contain chlorophylls, carotenoids, and xanthophylls, as well as pigments specific for this group: phycoerythrin and phycocyanin. The specific color and name of algae are related with the presence of these pigments in different quantitative proportions (Fig. 3-C) [135, 137, 138].

Carrageenans, a group of high-molecular-weight sulfated polysaccharides obtained from marine algae of the division Rhodophyta, attract particular attention as rich and renewable sources of phycocolloid polysaccharides [18, 135]. Currently, these structural components of algae membranes are considered as a promising resource of biopolymers with a unique structure and specific physical and chemical properties [20, 136-138].

The structure of these anionic sulfated polysaccharides (polygalactans) consists of alternating linear chains of $\alpha$-1,3-galactose and $\beta-1,4,3,6$-anhydrogalactose with ester sulfates (15$40 \%$ ) and resembles natural glycosoaminoglycans [18, 20, 135-137]. Depending on the degree of sulfation (from 15 to $40 \%$ ), solubility and source of extraction, six types of carrageenans are distinguished, of which $\varkappa$ (kappa), $\imath$ (iota) and $\lambda$ (lambda) are most fully characterized and studied [135-137]. The viscoelastic and gelling properties of these polysaccharides, as well as the presence of many functional groups in the structure (hydroxyl and sulfate), make these biopolymers a perfect material as a gelling agent in the design of hydrogel-based wound dressings with various chemical modifications $[138,139]$.

A few noteworthy reviews that focus on the transformation of carrageenan characteristics depending on changes in their structure and chemical and physical properties have been published in recent years [Zhang, Shankar, Zia, Cunha]. Therefore, based on the goals of the present review, we here focus only on the main trends in the use of these common and promising polysaccharides for wound healing as a basis for the design of various wound dressing types. 
Among various polysaccharides from red algae, $x$-carrageenan has certainly been studied best of all for the purpose of development of hydrogel-based wound dressings (as the most common type of wound dressing), since, in addition to biocompatibility, this biopolymer type exhibits pronounced hemostasiological and immunomodulatory properties necessary for healing $[135,140,141]$.

Hydrogels are formed as a result of heat-reversible gelation, ion cross-linking, or photocross-linking of methacrylate modifications of the backbone of this biopolymer $[137,138]$. In contrast to the simpler ionic cross-linking of polysaccharide in the presence of $\mathrm{K}^{+}$or $\mathrm{Ca}^{2+}$, leading to the formation of brittle hydrogels $[138,142]$, the incorporation of methacrylate groups of photocross-linking in the main $x$-carrageenan backbone, followed by activation with UV irradiation in the presence of a chemical photoinitiator, provided greater stability of reticulate gel [142, 143].

Gradient hydrogels based on $\varkappa$-carrageenan and gelatin have interesting healing properties, which have many advantages compared to conventional layered or mesh analogues [142]. The gradual and smooth variation in one of the physical properties of the material (viscosity, porosity, or density) simulates the tissue environment in vivo and has a positive effect on cell morphology $[138,142,143]$.

Promising types of $\boldsymbol{x}$-carrageenan-based hydrogels are nanogels that structurally contain medicinal nanoparticles of up to $100 \mathrm{~nm}$ and release them at a rate dependent on the temperature in the wound $\left(37-45^{\circ} \mathrm{C}\right)$, as well as hydrogels created by $3 \mathrm{D}$-bioprinting with the desired shape and specified mechanical properties and chemical structure [142, 143-145]. These forms of carrageenan-based hydrogels are excellent excipients for the prolonged release of not only antimicrobial agents, but also bioactive molecules, growth factors [143].

For example, in their recent study, H. Li with co-authors [144] has developed a promising strategy for three-dimensional bioprinting of a multilayer structure with strong interphase bonds using cationic (gelatin) and anionic ( $x$-carrageenan) hydrogels [144]. The proposed structure was not only strong, but also stable at $37^{\circ} \mathrm{C}$ that provided high viability of cells in the wound.

The various antiviral and antibacterial activities of carrageenans, as well as their antiinflammatory and immunomodulatory properties, revealed in recent years, have raised additional interest in them from the biotechnological and pharmaceutical aspect, as woundhealing biodressings $[135,136]$. The insufficient mechanical strength of these polysaccharides is compensated by the addition of various natural or synthetic polymers: polyvinylpyrrolidone, polyethylene oxide, polyvinyl alcohol, hyaluronic acid, or locust bean gum [137, 146, 147].

For example, in a recent experimental work, A.V. Nair with co-authors [149] studied the wound-healing properties of $\beta$ - $(1 \rightarrow 3)(1 \rightarrow 6)$ glucan/carrageenan hydrogels. The presence of 
carrageenan in the composition increased the porosity of gels and activated the attachment and proliferation of fibroblasts in experiments in vivo and in vitro, with a more rapid wound healing as compared to the control [149].

Intact skin is known to have slightly acidic $\mathrm{pH}$ values (4.0-6.0); with bacterial infection, $\mathrm{pH}$ increases to an alkaline level (up to 9.0). Colonization of wounds by pathogenic bacteria negatively affects treatment, and, therefore, controlling $\mathrm{pH}$ as a biomarker of infection is important for assessment and monitoring of healing [150].

K. Zepon with co-authors [137] have reported, for the first time, the development of an combined "smart" wound dressing: a $\mathrm{pH}$-sensitive hydrogel film based on covalent binding of $x$ carrageenan polysaccharide, locust bean (Ceratonia siliqua) gum, and cranberry extract [137]. In this design, locust bean gum enhanced the mechanical properties of carrageenan hydrogel. Another component of the coating, the anthocyanin-rich cranberry extract, is not only an antibacterial agent, but also acts as a sensitive $\mathrm{pH}$ indicator which changes its color in case of alkaline reaction in the wound fluid, thus, indicating bacterial infection [137].

Thus, due to their almost perfect physical and chemical properties, carrageenans have found a wide range of applications as a basis for designing wound dressings. The presence of several functional groups in the composition, the high hydrophilicity, and a strong negative charge of these polysaccharides allow modification of their properties and enhancement of their biological activity in a wide range.

\section{Ulvans}

Ulvans, classified as a group of sulfated heteropolysaccharides, are among the main biopolymers extracted from cell wall of some members of green algae, the class Ulvales (species of Ulva, Enteromorpha, and Utricularia). Ulvans, being a component of cell wall, provide osmotic stability and cell protection along with other polysaccharides of these algae (cellulose, xyloglucan, and glucoronan), making up to $45 \%$ of dry weight (Fig. 3-D). [20, 151, 152].

The chemical composition of ulvans strongly depends on the species of algae, the season of their collection, the habitat conditions during growth, and extraction methods. The typical structure of these polyanion heteropolysaccharides is represented by rhamnose, xylose, glucose, galactose, uronic acids (glucuronic and iduronic), as well as by sulfate and carboxyl groups structured as the main ulvanobiuronic (aldobiuronic) acid disaccharides designated as glucurorhamnose 3-sulfate (types A) and iduronorhamnose 3-sulfate (type B) $[18,154]$.

Ulvans are almost insoluble in organic solvents, which is explained by the relative hydrophobicity of rhamnose [20,153-156]. This property limits the opportunities of chemical modifications of ulvans and prevents their potentially common application in the wound dressing 
design [151, 156, 157]. However, in solutions with high $\mathrm{pH}$, the conformation of these polysaccharides increases the intermolecular interactions in the wound, which makes it possible to obtain hydrogels with high viscosity $[152,153,155]$. This feature allows transformation of polysaccharide's gel-forming properties by manipulating the structural and functional relationships [152, 154].

The presence of charged sulfate and carboxyl groups in the structure complicates obtaining mechanically stable hydrogels, which is associated with the active water absorption and development of hydrolytic degradation $[151,153,156]$. When wound dressings are designed, these structural features of ulvans necessitate, on the one hand, solving the problem of their preliminary modification to make them insoluble and, on the other hand, increasing the mechanical properties of gels $[153,156]$. The latter problem is solved by creating complex ionotropic gel complexes with cationic polymers or inorganic additives such as boric acid, copper, calcium, zinc, or magnesium $[153,158]$.

The presence of rare carbohydrates, iduronic acid, and sulfated rhamnose in the biochemical profile of ulvans is a feature distinguishing them from other seaweed-derived polysaccharides $[155,159]$. Thus, the presence of rhamnose enhances the biological activity of ulvans, especially in the treatment of skin pathologies (by influencing the biosynthetic pathways in dermis), and also improves wound-healing properties (by reducing bacterial adhesion and stimulating cell proliferation and collagen biosynthesis) [152, 159, 160-162].

The primary structure of these polysaccharides is directly related to the wide range of their macromolecular properties that determine the pharmacological attractiveness of ulvans and their potential to be used in biomedicine. Experimental and model studies have revealed significant antioxidant [13, 153, 155], anticoagulant [15, 153, 154], antitumor [17, 152, 156, 157], antihyperlipidemic $[13,17,152,153]$, and immunomodulatory $[13,16,154,159]$ biological activities of ulvans, both in vitro and in vivo. Moreover, ulvans, like all seaweed-derived sulfated polysaccharides, exhibit a wide range of antiviral activities. These biological features of ulvanes have found application not only in the treatment of a number of diseases as a preventive antibiofilm agent, but also in the design of bandages for wound treatment and tissue engineering [152, $155,157,161,162]$.

An example of successful application of the physical and chemical properties of this polysaccharide is the development of an ulvan-chitosan polyion complex gel by K. Kanno with co-authors, which proved to be more stable than an alginic acid-chitosan gel under both in acidic and basic conditions. However, under model conditions, this complex was inferior to the heparinchitosan gel-coated vessel in terms of anticoagulant properties [154]. 
Thus, compared to other seaweed-derived polysaccharides, studies on the biological properties of ulvans and their biotechnological potential for creating wound dressings are only at an initial stage. The structural features of these complex biopolymers require more attention to elucidate their effect on the stages of wound process for the subsequent development of substantiated proposals on their use in specific types of wound dressings.

\section{Conclusion}

Seaweed-derived sulfated polysaccharides are a new and promising biologically active source for creating wound dressings. The significant structural diversity and presence of various functional groups provide their high potential in managing the wound healing process and stimulating the mechanisms of natural skin regeneration. The hydrophilic property of these marine polysaccharides ensures their ability to form hydrogels that can absorb exudates from wounds and create a moist environment necessary for successful healing.

Various types of wound dressings based on alginates, fucoidans, carrageenans, and ulvans act as active and effective therapeutic tools. They are involved in wound healing not only as a natural dermis simulator, but also as functional biomaterials for controlled drug delivery, cell immobilization, and tissue bioengineering technologies.

Being simple in cultivation and nonfastidious in nutrition, marine algae have become an inexhaustible natural resource of valuable polysaccharides with unique biological properties. Over the past decades, they have turned into an attractive alternative to synthetic dressings.

The experience of experimental studies on the feasibility of pathophysiological regulation of wound healing phases using sulfated polysaccharides has been accumulated for years of research, in parallel with the extension of our knowledge about the pathogenetic mechanisms of wound processes. This required summarizing the clinical studies and analyzing the effectiveness of various types of wound dressings with marine biopolymers based on the objective results obtained.

The abundance of attractive and promising technologies for the creation of natural dressings based on sulfated polysaccharides necessitates finding a scientifically grounded approach to wound treatment and developing relevant practical recommendations. This will allow wider opportunities for their application in treatment of wounds of various etiologies.

The future prospects for using seaweed-derived sulfated polysaccharides largely depend on the interaction between clinicians and biotechnologists engaged in the development and testing of modern dressings. Nevertheless, the search for novel wound dressings based on seaweed-derived polysaccharides, as well as for the forms of their application, is far from being completed. 


\section{Funding of the study:}

The study was supported by the "Far East" Integrated Program of Basic Research, Far Eastern Branch, Russian Academy of Sciences, project no. 18-03-059.

\section{Conflict of interests:}

The authors are declaring no conflict of interest.

\section{Author contributions:}

BGA - concept, methodology, approval of the final review; NNB - idea and writing plan, approval of the final version; TAK - writing a conclusion and conclusion, proofreading an article; TSZ - Methodology, Conceptualization, Validation; AKG - editing and validation of an article, collection and analysis of literature data; EAC - analysis and interpretation of data, preparation of the original layout; SPE - collection of material, verification and proofreading of technical details and terms; TNZ - collecting material, preparing a draft text, preparing illustrations, preparation of a draft manuscript; TPS - collection and analysis of literature, preparation of a draft manuscript.

\section{References}

1. Basu S., Shukla V. Complications of Wound Healing. In: Mani R., Romanelli M., Shukla V. (eds) Measurements in Wound Healing. Springer, London. 2012. C. 109-144.

2. Bilal M, Iqbal HMN. Marine Seaweed Polysaccharides-Based Engineered Cues for the Modern Biomedical Sector. Mar Drugs. 2019;18(1):7. Published 2019 Dec 19. doi:10.3390/md18010007.

3. Weller C.D., Team V., Sussman G. First-Line Interactive Wound Dressing Update: A Comprehensive Review of the Evidence. Front Pharmacol. 2020; 11:155. doi: 10.3389/fphar.2020.00155.

4. Dabiri G., Damstetter E., Phillips T. Choosing a Wound Dressing Based on Common Wound Characteristics. Adv Wound Care (New Rochelle). 2016; 5(1):32-4

5. Bryant R., Nix D. Acute and Chronic Wounds. 5th Ed. Mosby, 2016. 648 p.

6. Dhivya S., Padma V.V., Santhini E. Wound dressings - a review. Biomedicine (Taipei). 2015; 5(4):22. doi: 10.7603/s40681-015-0022-9.

7. Shah J.B. The history of wound care. J Am Col Certif Wound Spec. 2011;3(3):65-6. doi: 10.1016/j.jcws.2012.04.002.

8. Mouës C.M., Heule F., Legerstee R., Hovius S.E. Five millennia of wound care products-what is new? A literature reviews. Ostomy Wound Manage. 2009; 55(3):16-22. 
9. Shah J.B. The history of wound care. J Am Col Certif Wound Spec. 2011; 3(3):65-66. doi: 10.1016/j.jcws.2012.04.002.

10. Aduba D.C., Yang H. Polysaccharide Fabrication Platforms and Biocompatibility Assessment as Candidate Wound Dressing Materials. Bioengineering (Basel). 2017; 4(1):1. doi:10.3390/bioengineering4010001.

11. Sweeney IR, Miraftab M, Collyer G. A critical review of modern and emerging absorbent dressings used to treat exuding wounds. Int Wound J. 2012; 9(6):601-12. doi: 10.1111/j.1742481X.2011.00923. x.

12. Zhou J, Yao D, Qian Z, Hou S, Li L, Jenkins ATA, Fan Y. Bacteria-responsive intelligent wound dressing: Simultaneous In situ detection and inhibition of bacterial infection for accelerated wound healing. Biomaterials. 2018; 161:11-23. doi: 10.1016/j.biomaterials.2018.01.024.

13. Jiao G., Yu G., Zhang J., Ewart H.S. Chemical structures and bioactivities of sulfated polysaccharides from marine algae. Mar Drugs. 2011; 9(2):196-223. doi: 10.3390/md9020196.

14. Ngo D.H., Kim S.K. Sulfated polysaccharides as bioactive agents from marine algae. Int J Biol Macromol. 2013; 62:70-75. doi: 10.1016/j.ijbiomac.2013.08.036.

15. Khotimchenko Yu.S. Biologically active substances from marine aquatic organisms - a source of new pharmaceutical substances and medicines // Pacific Medical Journal, 2010; 2: 5-9 (in Russ.).

16. Kuznetsova T.A., Besednova N.N., Somova L.M., Makarenkova I.D., Plekhova N.G., Drobot E.I., Kovalev N.N., Usov V.V. Experimental evaluation of the effectiveness of wound dressings based on biologically active substances from marine hydrobionts Russian Journal of Marine Biology. 2016; 42(5): 427-432 (in Russ.). doi: 10.1134/S1063074016060055.

17. Besednova N.N., Smolina TP, Andryukov B.G., Kuznetsova T.A., Mikhailov V.V., Zvyagintseva T.N. Exopolysaccharides of marine bacteria: prospects for use in medicine. Antibiotics and chemotherapy. 2018.Vol. 63. No. 7-8. S. 67-78 (in Russ.).

18. Algae Biomass: Characteristics and Applications: Towards Algae-based Products. By Editors: K. Chojnacka, P.P. Wieczorek, G. Schroeder and I. Michalak. Switzerland, Cham (ZG): Springer Int. Publ. AG, 2018. 143 p. Doi: 10.1007/978-3-319-74703-3.

19. Leandro A, Pereira L, Gonçalves AMM. Diverse Applications of Marine Macroalgae. Mar Drugs. 2019;18(1):17. doi:10.3390/md18010017.

20. Marine Algae Extracts. Process, Product and Application. Ed. By Se-Kwon Kim and Katarzyna Chojnacka. Vol. 2. Germany, Wiley, 2015. 724 p.

21. Ribeiro DML, Carvalho Júnior AR, Vale de Macedo GHR, Chagas VL, Silva LDS, Cutrim BDS, Santos DM, Soares BLL, Zagmignan A, de Miranda RCM, de Albuquerque PBS, Nascimento da Silva LC. Polysaccharide-Based Formulations for Healing of Skin-Related Wound 
Infections: Lessons from Animal Models and Clinical Trials. Biomolecules. 2019; 10(1). pii: E63. doi: 10.3390/biom10010063.

22. Flanagan M. Wound Healing and Skin Integrity: Principles and Practice. John Wiley \& Sons, 2013. 312 p.

23. Boateng J.S., Matthews K.H., Stevens H.N.E., Eccleston G.M. Wound healing dressings and drug delivery systems: a review. J. Pharm. Sci., 97 (8), 2892-2923. DOI: 10.1002/jps.21210.

24. Thomas S. A guide to dressing selection. J. Wound Care, 1997; 6 (10): 479-482. doi: 10.12968/jowc.1997.6.10.479.

25. Gurtner G.C., Werner S., Barrandon Y., Longaker M.T. Wound repair and regeneration. Nature. 2008; 453(7193): 314-321. doi: 10.1038/nature07039.

26. Dreifke MB, Jayasuriya AA, Jayasuriya AC. Current wound healing procedures and potential care. Mater Sci Eng C Mater Biol Appl. 2015; 48:651-662. doi: 10.1016/j.msec.2014.12.068

27. Sahana TG, Rekha PD. Biopolymers: Applications in wound healing and skin tissue engineering. Mol Biol Rep. 2018;45(6):2857-2867. doi: 10.1007/s11033-018-4296-3.

28. Chang H., Wind S., Kerstein M.D. Moist wound healing. Dermatol Nurs. 1996; 8(3):1746, 204.

29. Boateng J, Catanzano O. Advanced Therapeutic Dressings for Effective Wound Healing-A Review. J Pharm Sci. 2015; 104(11):3653-3680. doi: 10.1002/jps.24610.

30. Shiva Krishna P, Sudha S, Reddy KA, et al. Studies on wound healing potential of red pigment isolated from marine Bacterium Vibrio sp. Saudi J Biol Sci. 2019; 26(4):723-729. doi: 10.1016/j.sjbs.2017.11.035.

31. Deutsch C.J., Edwards D.M., Myers S. Wound dressings. Br J Hosp Med (Lond). 2017; 78(7):C103-C109. doi: 10.12968/hmed.2017.78.7.C103.

32. Morton LV, Phillips TJ. Wound healing update. Semin. Cutan. Med. Surg., 2012. 31(1): 33-37. doi: 10.1016/j.sder.2011.11.007.

33. Es-Haghi A, Mashreghi M, Rezazade Bazaz M, Homayouni-Tabrizi M, Darroudi M. Fabrication of biopolymer-based nanocomposite wound dressing: evaluation of wound healing properties and wound microbial load. IET Nanobiotechnol. 2017; 11(5):517-522. doi: 10.1049/ietnbt.2016.0160.

34. Noël B., Charbonneau L. Modern wound dressings. Praxis (Bern 1994). 2008; 97(5):265268. DOI: $10.1024 / 1661-8157.97 .5 .265$

35. Borkow G, Okon-Levy N, Gabbay J. Copper oxide impregnated wound dressing: biocidal and safety studies. Wounds. 2010 Dec;22(12):301-10. 
36. Tracy LE, Minasian RA, Caterson EJ. Extracellular Matrix and Dermal Fibroblast Function in the Healing Wound. Adv Wound Care (New Rochelle). 2016; 5(3):119-136. doi:10.1089/wound.2014.0561.

37. Sang-Myung Jung, Seul Ki Min, Hoo Chul Lee, Yeo Seon Kwon, Moon Hee Jung, Hwa Sung Shin Spirulina-PCL Nanofiber Wound Dressing to Improve Cutaneous Wound Healing by Enhancing Antioxidative Mechanism. Journal of nanomaterials, 2016; ID 6135727. doi: $10.1155 / 2016 / 6135727$

38. Vinnik I.S., Markelova N.M., Solov'eva N.S., Shishatskaia E.I., Kuznetsov M.N., Zuev A.P. The Current Dressings for Wound Care in the Treatment of Purulent Wounds. Novosti Khirurgii. 2015; 23 (5): 552-558. doi: 10.18484/2305-0047.2015.5.552.

39. Frykberg R.G., Banks J. Challenges in the Treatment of Chronic Wounds. Adv Wound Care (New Rochelle). 2015; 4(9):560-582. doi:10.1089/wound.2015.0635.

40. Vrana N., Knopf-Marques H., Barthes J. Biomaterials for Organ and Tissue Regeneration: New Technologies and Future Prospects. Woodhead Publishing, 2020. - 846 p.

41. High Performance Biomaterials: A Complete Guide to Medical and Pharmaceutical applications. By ed. M. Szycher. USA: Lancaster-Basel, 1991. 824 p.

42. Natural Polymer Drug Delivery Systems: Nanoparticles, Plants, and Algae. By Ed. Saurabh Bhatia. India, Gurgaon: Shpringer, 2016. 225 p.

43. Vigani B, Rossi S, Sandri G, Bonferoni MC, Caramella CM, Ferrari F. Hyaluronic acid and chitosan-based nanosystems: a new dressing generation for wound care.Expert Opin Drug Deliv. 2019 Jul;16(7):715-740. doi: 10.1080/17425247.2019.1634051.

44. Sun ML, Zhao F, Chen XL, Zhang XY, Zhang YZ, Song XY, Sun CY, Yang J. Promotion of Wound Healing and Prevention of Frostbite Injury in Rat Skin by Exopolysaccharide from the Arctic Marine Bacterium Polaribacter sp. SM1127. Mar Drugs. 2020; 18(1). pii: E48. doi: $10.3390 / \mathrm{md} 18010048$.

45. Sun M.L., Zhao F., Shi M., Zhang X.Y., Zhou B.C., Zhang Y.Z., Chen X.L. Characterization and Biotechnological Potential Analysis of a New Exopolysaccharide from the Arctic Marine Bacterium Polaribacter sp. SM1127. Sci Rep. 2015; 5:18435. doi: $10.1038 /$ srep 18435.

46. Sahana T.G., Rekha P.D. A bioactive exopolysaccharide from marine bacteria Alteromonas sp. PRIM-28 and its role in cell proliferation and wound healing in vitro. Int J Biol Macromol. 2019; 131:10-18. doi: 10.1016/j.ijbiomac.2019.03.048.

47. Delbarre-Ladrat C, Sinquin C, Lebellenger L, Zykwinska A, Colliec-Jouault S. Exopolysaccharides produced by marine bacteria and their applications as glycosaminoglycan-like molecules. Front Chem. 2014; 2:85. doi: 10.3389/fchem.2014.00085. 
48. Casillo A, Lanzetta R, Parrilli M, Corsaro MM. Exopolysaccharides from Marine and Marine Extremophilic Bacteria: Structures, Properties, Ecological Roles and Applications. Mar Drugs. 2018;16(2):69. doi:10.3390/md16020069.

49. Delattre C., Pierre G., Laroche C., Michaud P. Production, extraction and characterization of microalgal and cyanobacterial exopolysaccharides. Biotechnol. Adv. 2016; 34: 1159-1179. doi: 10.1016/j.biotechadv.2016.08.001.

50. Ovington L. The Evolution of Wound Management. Home Healthcare Nurse 2020; 20(10):652-656. doi: 10.1097/00004045-200210000-00009.

51. Zahedi P., Rezaeian I., Ranaei-Siadat S.O., Jafari S.H., Supaphol P. A review on wound dressings with an emphasis on electrospun nanofibrous polymeric bandages. Polym. Adv. Technol. 2010; 21:77-95. doi: 10.1002/pat.1625.

52. Sood A., Granick M.S., Tomaselli N.L. Wound dressings and comparative effectiveness data. Adv. Wound Care. 2014; 3:511-529. doi: 10.1089/wound.2012.0401.

53. Laurienzo P. Marine polysaccharides in pharmaceutical applications: An overview. Mar. Drugs 2010; 8: 2435-2465. doi: 10.3390/md8092435.

54. Liu S.-B., Qiao L.-P., He H.-L., Zhang Q., Chen X.-L., Zhou W.-Z., Zhou B.-C., Zhang Y.-Z. Optimization of fermentation conditions and rheological properties of exopolysaccharide produced by deep-sea bacterium Zunongwangia profunda SM-A87. PLoS ONE 2011; 6: e26825. doi: 10.1371/journal.pone.0026825.

55. de Jesus Raposo MF, de Morais AM, de Morais RM. Marine polysaccharides from algae with potential biomedical applications. Mar Drugs. 2015; 13(5):2967-3028. doi:10.3390/md13052967.

56. Florez N, Gonzalez-Munoz MJ, Ribeiro D, Fernandes E, Dominguez H, Freitas M. Algae Polysaccharides' Chemical Characterization and their Role in the Inflammatory Process. Curr Med Chem. 2017;24(2):149-175. doi: 10.2174/0929867323666161028160416.

57. Broussard KC, Powers JG. Wound dressings: selecting the most appropriate type. Am J Clin Dermatol. 2013; 14(6):449-459. doi:10.1007/s40257-013-0046-4.

58. Winter G.D., Scales J.T. Effect of air drying and dressings on the surface of a wound. Nature. 1963; 197:91-92. doi:10.1038/197091b0.

59. Hinman C.D., Maibach H. Effect of air exposure and occlusion on experimental human skin wounds. Nature. 1963; 200:377-378. doi:10.1038/200377a0.

60. Wang L, Wang X, Wu H, Liu R. Overview on biological activities and molecular characteristics of sulfated polysaccharides from marine green algae in recent years. Mar Drugs. 2014;12(9):4984-5020. Published 2014 Sep 25. doi:10.3390/md12094984. 
61. Kiuru P, D’Auria MV, Muller CD, Tammela P, Vuorela H, Yli-Kauhaluoma J. Exploring marine resources for bioactive compounds. Planta Med. 2014; 80(14):1234-1246. doi: 10.1055/s0034-1383001.

62. Cardoso MJ, Costa RR, Mano JF. Marine Origin Polysaccharides in Drug Delivery Systems. Mar Drugs. 2016;14(2):34. Published 2016 Feb 5. doi: 10.3390/md14020034.

63. Okabayashi K, Ashrafian H, Zacharakis E, Hasegawa H, Kitagawa Y, Athanasiou T et al. Adhesions after abdominal surgery: A systematic review of the incidence, distribution and severity. Surgery Today 2014; 44:405. doi: 10.1007/s00595-013-0591-8-page-1. Спайки

64. Blunden G. Biologically active compounds from marine organisms. Phytother Res. 2001; 15(2):89-94. doi: 10.1002/ptr.982.

65. Halim AS, Khoo TL, Saad AZ. Wound bed preparation from a clinical perspective. Indian J Plast Surg. 2012; 45(2):193-202. doi: 10.4103/0970-0358.101277. Концепция ТIME

66. Leaper DJ, Schultz G, Carville K, Fletcher J, Swanson T, Drake R. Extending the TIME concept: what have we learned in the past 10 years? Int Wound J. 2012; 9 Suppl 2:1-19. doi: 10.1111/j.1742-481X.2012.01097. x.

67. Pilcher M. Wound cleansing: a key player in the implementation of the TIME paradigm. J Wound Care. 2016; 25(3 Suppl):S7-9. doi: 10.12968/jowc.2016.25.Sup3.S7.

68. Garcia-Vaquero M., Rajauria G., O'Doherty J.V., Sweeney T. Polysaccharides from macroalgae: Recent advances, innovative technologies and challenges in extraction and purification. Food Res Int. 2017; 99(Pt 3):1011-1020. doi: 10.1016/j.foodres.2016.11.016.

69. Kordjazi M, Shabanpour B, Zabihi E, et al. Sulfated polysaccharides purified from two species of padina improve collagen and epidermis formation in the rat. Int J Mol Cell Med. 2013; 2(4):156-163.

70. Pan H, Fan D, Duan Z, Zhu C, Fu R, Li X. Non-stick hemostasis hydrogels as dressings with bacterial barrier activity for cutaneous wound healing. Mater Sci Eng C Mater Biol Appl. 2019; 105:110118. doi: 10.1016/j.msec.2019.110118.

71. Dhaliwal K, Lopez N. Hydrogel dressings and their application in burn wound care. Br J Community Nurs. 2018; 23(Sup9): S24-S27. doi: 10.12968/bjen.2018.23.Sup9.S24

72. Cunha L., Grenha A. Sulfated seaweed polysaccharides as multifunctional materials in drug delivery applications. Marine Drugs, 2016; 14(3): 42.

73. Zhang Z., Wang X., Wang Y., Hao J. Rapid-Forming and Self-Healing Agarose-Based Hydrogels for Tissue Adhesives and Potential Wound Dressings. Biomacromolecules. 2018; 19(3):980-988. doi: 10.1021/acs.biomac.7b01764. 
74. Dobrinčić A., Balbino S., Zorić Z., Pedisić S., Bursać-Kovačević D., Garofulić I. E., Dragović-Uzelac V. Advanced Technologies for the Extraction of Marine Brown Algal Polysaccharides. Mar Drugs. 2020; 18(3): pii: E168. doi: 10.3390/md18030168.

75. Cunha L., Grenha A. Sulfated seaweed polysaccharides as multifunctional materials in drug delivery applications. Marine Drugs, 2016; 14(3), 42. doi: 10.3390/md14030042.

76. Menshova R.V., Shevchenko N.M., Imbs T.I., Zvyagintseva T.N., Malyarenko O.S., Ermakova S.P., Zaporoshets T.S., Besednova N.N. Fucoidans from brown alga Fucus evanescens: structure and biological activity. Frontiers in Marine Science. 2016; 3(39): 129. doi: 10.3389/fmars.2016.00129.

77. Abasalizadeh F., Moghaddam S.V., Alizadeh E., Akbari E., Kashani E., Fazljou S.M.B., Torbati M., Akbarzadeh A. Alginate-based hydrogels as drug delivery vehicles in cancer treatment and their applications in wound dressing and 3D bioprinting. J Biol Eng. 2020; 14:8. doi: 10.1186/s13036-020-0227-7.

78. Kaiser D, Hafner J, Mayer D, French LE, Läuchli S. Alginate dressing and polyurethane film versus paraffin gauze in the treatment of split-thickness skin graft donor sites: a randomized controlled pilot study. Adv Skin Wound Care. 2013; 26(2):67-73. doi: 10.1097/01.ASW.0000426715.57540.8d

79. Williams C. Kaltostat. Br J Nurs. 1994; 3(18):965-967. doi: 10.12968/bjon.1994.3.18.965.

80. Aderibigbe BA, Buyana B. Alginate in Wound Dressings. Pharmaceutics. 2018;10(2):42. Published 2018; 10(2):42. doi:10.3390/pharmaceutics10020042.

81. Lee K.Y., Mooney D.J. Alginate: Properties and biomedical applications. Prog. Polym. Sci. 2012; 37:106-126. doi: 10.1016/j.progpolymsci.2011.06.003.

82. Kamoun E.A., Kenawy E.R., Chen X. A review on polymeric hydrogel membranes for wound dressing applications: PVA-based hydrogel dressings. J. Adv. Res. 2017; 8:217-233. doi: 10.1016/j.jare.2017.01.005.

83. Straccia M.C., d'Ayala G.G., Romano I., Oliva A., Laurienzo P. Alginate hydrogels coated with chitosan for wound dressing. Mar. Drugs. 2015; 13:2890-2908. doi: 10.3390/md13052890.

84. Ching S.H., Bansal N., Bhandari B. Alginate gel particles-A review of production techniques and physical properties. Crit. Rev. Food Sci. Nutr. 2017; 57:1133-1152. doi: 10.1080/10408398.2014.965773.

85. Boateng J., Burgos-Amador R., Okeke O., Pawar H. Composite alginate and gelatinbased bio-polymeric wafers containing silver sulfadiazine for wound healing. Int. J. Biol. Macromol. 2015; 79:63-71. doi: 10.1016/j.ijbiomac.2015.04.048. 
86. Pawar H.V., Boateng J.S., Ayensu I., Tetteh J. Multifunctional medicated lyophilised wafer dressing for effective chronic wound healing. J. Pharm. Sci. 2014; 103:1720-1733. doi: 10.1002/jps.23968.

87. Murakami K, Ishihara M, Aoki H, Nakamura S, Nakamura S, Yanagibayashi S, Takikawa M, Kishimoto S, Yokoe H, Kiyosawa T, Sato Y. Enhanced healing of mitomycin C-treated healing-impaired wounds in rats with hydrosheets composed of chitin/chitosan, fucoidan, and alginate as wound dressings. Wound Repair Regen. 2010; 18(5):478-485. doi: 10.1111/j.1524475X.2010.00606. X.

88. Williams C. Role of CarboFlex in the nursing management of wound odour. Br J Nurs. 2001;10(2):122-125. doi:10.12968/bjon.2001.10.2.5395.

89. Lee S.M., Park I.K., Kim Y.S., Kim H.J., Moon H., Mueller S., Jeong Y.I. Physical, morphological, and wound healing properties of a polyurethane foam-film dressing. Biomater. Res. 2016; 20:11.

90. Thomas S. Alginate dressings in surgery and wound management--Part 1. J Wound Care. 2000;9(2):56-60. doi:10.12968/jowc.2000.9.2.26338.

91. Stoica AE, Chircov C, Grumezescu AM. Nanomaterials for Wound Dressings: An Upto-Date Overview. Molecules. 2020;25(11): E2699. doi:10.3390/molecules25112699.

92. Fertah M., Belfkira A., Taourirte M., Brouillette F. Extraction and characterization of sodium alginate from Moroccan Laminaria digitata brown seaweed. Arab. J. Chem. 2017; 10: S3707-S3714. doi: 10.1016/j.arabjc.2014.05.003.

93. Fan C, Pek CH, Por YC, Lim GJS. Biobrane dressing for paediatric burns in Singapore: a retrospective review. Singapore Med J. 2018;59(7):360-365. doi:10.11622/smedj.2017116.

94. McBride CA, Kimble RM, Stockton KA. Prospective randomised controlled trial of Algisite $^{\mathrm{TM}} \mathrm{M}$, Cuticerin ${ }^{\mathrm{TM}}$, and Sorbact ${ }^{\circledR}$ as donor site dressings in paediatric split-thickness skin grafts. Burns Trauma. 2018; 6:33. doi:10.1186/s41038-018-0135-y.

95. Thomas S. Alginate dressings in surgery and wound management: Part 2. J Wound Care. 2000;9(3):115-119. doi:10.12968/jowc.2000.9.3.25959.

96. Totty JP, Bua N, Smith GE, et al. Dialkylcarbamoyl chloride (DACC)-coated dressings in the management and prevention of wound infection: a systematic review. J Wound Care. 2017;26(3):107-114. doi:10.12968/jowc.2017.26.3.107.

97. Thomas S. Alginate dressings in surgery and wound management: Part 3. J Wound Care. 2000;9(4):163-166. doi:10.12968/jowc.2000.9.4.25973

98. Hiro ME, Pierpont YN, Ko F, Wright TE, Robson MC, Payne WG. Comparative evaluation of silver-containing antimicrobial dressings on in vitro and in vivo processes of wound healing. Eplasty. 2012;12:e48. 
99. Pires ALR, de Azevedo Motta L, Dias AMA, de Sousa HC, Moraes ÂM, Braga MEM. Towards wound dressings with improved properties: Effects of poly(dimethylsiloxane) on chitosan-alginate films loaded with thymol and beta-carotene. Mater Sci Eng C Mater Biol Appl. 2018; 93:595-605. doi: 10.1016/j.msec.2018.08.005.

100.Rezvanian M., Amin M.C., Ng S.F. Development and physicochemical characterization of alginate composite film loaded with simvastatin as a potential wound dressing. Carbohydr. Polym. 2016; 137:295-304. doi: 10.1016/j.carbpol.2015.10.091.

101.Fallacara A, Baldini E, Manfredini S, Vertuani S. Hyaluronic Acid in the Third Millennium. Polymers (Basel). 2018;10(7):701. doi:10.3390/polym10070701

102.Catanzano O, D'Esposito V, Acierno S, Ambrosio MR, De Caro C, Avagliano C, Russo P, Russo R, Miro A, Ungaro F, Calignano A, Formisano P, Quaglia F. Alginate-hyaluronan composite hydrogels accelerate wound healing process. Carbohydr Polym. 2015; 131:407-14. doi: 10.1016/j.carbpol.2015.05.081.

103.Hajiali H., Summa M., Russo D., Armirotti A., Brunetti V., Bertorelli R., Athanassiou A., Mele E. Alginate-lavender nanofibers with antibacterial and anti-inflammatory activity to effectively promote burn healing. J. Mater. Chem. B. 2016; 4:1686-1695. doi: 10.1039/C5TB02174J.

104.Hu C., Gong R.H., Zhou F.L. Electrospun sodium alginate/polyethylene oxide fibers and nanocoated yarns. Int. J. Polym. Sci. 2015; 2015:1-12. doi: 10.1155/2015/126041.

105.Mohandas A., Sudheesh Kumar P.T., Raja B., Lakshmanan V.K., Jayakumar R. Exploration of alginate hydrogel/nano zinc oxide composite bandages for infected wounds. Int. J. Nanomed. 2015; 10:53-66.

106. Xie H., Chen X., Shen X., He Y., Chen W., Luo Q., Ge W., Yuan W., Tang X., Hou D., et al. Preparation of chitosan-collagen-alginate composite dressing and its promoting effects on wound healing. Int. J. Biol. Macromol. 2018, 107, 93-104. doi: 10.1016/j.ijbiomac.2017.08.142.

107.Li S., Li L., Guo C., Qin H., Yu X. A promising wound dressing material with excellent cytocompatibility and proangiogenesis action for wound healing: Strontium loaded Silk fibroin/Sodium alginate (SF/SA) blend films. Int. J. Biol. Macromol. 2017; 104:969-978. doi: 10.1016/j.ijbiomac.2017.07.020.

108. Mohiuddin A.K. The Role of the Pharmacist in Patient Care: Achieving High Quality, CostEffective and Accessible Healthcare Through a Team-Based, Patient-Centered Approach. Irvine, California \& Boca Raton, Florida, USA: Universal-Publishers, Inc. 2020 - 690 p.

109.ALGICELL ${ }^{\circledR}$. Available online: https://www.woundsource.com/product/algicellalginate-wound-dressings (accessed on 07 June 2020). 
110. ALGISIGHTтм. Available online: https://www.woundsource.com/product/algisite-m-calciumalginate-dressing (accessed on 07 June 2020).

111.AMERX ${ }^{\text {тм}}$. Available online: https://www.woundsource.com/product/amerx-calciumalginate-dressings (accessed on 07 June 2020).

112.Biatain®Alginate. Available online: https://www.coloplast.ca/biatain-alginate-enca.aspx (accessed on 08 June 2020).

113. CovaWound ${ }^{\mathrm{TM}}$ Alginate. Available online: https://www.woundsource.com/product/ covawound-alginate-alginate-dressing (accessed on 06 June 2020).

114. ExcelGinate. Available online: https://www.woundsource.com/product/excelginate (accessed on 17 May 2020).

115.Fibracol ${ }^{\mathrm{TM}}$ Plus Collagen Wound Dressing with Alginate. Available online: http://www.woundsource.com/product/fibracol-plus-collagen-wound-dressing-alginate (accessed on 17 May 2020).

116. GEMCORE $360^{\circ}$ тм Reinforced Alginate Wound Dressings. Available online: https://www.woundsource.com/product/gemcore360-reinforced-alginate-wound-dressings (accessed 17 May 2020).

117. Kalginate ${ }^{\mathrm{TM}}$ Thin. Available online: https://www.woundsource.com/product/kalginate-thin (accessed 17 May 2020).

118.3 $\mathrm{M}^{\mathrm{TM}}$ Tegaderm ${ }^{\mathrm{TM}}$ High Integrity и $3 \mathrm{M}^{\mathrm{TM}}$ Tegaderm ${ }^{\mathrm{TM}}$ High Gelling Alginate Dressings. Available online: https://www.woundsource.com/product/3m-tegaderm-high-integrity-and-3mtegaderm-high-gelling-alginate-dressings (accessed on 06 June 2020).

119.Jenks M, Craig J, Green W, Hewitt N, Arber M, Sims A. Tegaderm CHG IV Securement Dressing for Central Venous and Arterial Catheter Insertion Sites: A NICE Medical Technology Guidance. Appl Health Econ Health Policy. 2016;14(2):135-149. doi:10.1007/s40258-015-0202-5.

120. Park JH, Choi SH, Park SJ, et al. Promoting Wound Healing Using Low Molecular Weight Fucoidan in a Full-Thickness Dermal Excision Rat Model. Mar Drugs. 2017;15(4):112. Published 2017 Apr 7. doi:10.3390/md15040112.

121.Li B., Lu F., Wei X., Zhao R. Fucoidan: structure and bioactivity. Molecules. 2008; 13:1671-1695. doi: 10.3390/molecules13081671.

122.Luthuli S., Wu S., Cheng Y., Zheng X., Wu M., Tong H. Therapeutic Effects of Fucoidan: A Review on Recent Studies. Mar Drugs. 2019;17(9):487. Published 2019 Aug 21. doi:10.3390/md17090487.

123.Fitton H.J., Stringer D.S., Park A.Y., Karpiniec S.N. Therapies from Fucoidan: New Developments. Mar Drugs. 2019; 17(10):571. doi:10.3390/md17100571. 
124.Zayed A, Ulber R. Fucoidans: Downstream Processes and Recent Applications. Mar Drugs. 2020;18(3):170. Published 2020 Mar 18. doi:10.3390/md18030170.

125.Benbow N.L., Webber J.L., Karpiniec S., Krasowska M., Ferri J.K., Beattie D.A. The influence of polyanion molecular weight on polyelectrolyte multilayers at surfaces: protein adsorption and protein-polysaccharide complexation/stripping on natural polysaccharide films on solid supports. Phys. Chem. Chem. Phys. 2017; 19:23790-23801. doi: 10.1039/C7CP02599H.

126.Nakamura T, Mizuno S. The discovery of hepatocyte growth factor (HGF) and its significance for cell biology, life sciences and clinical medicine. Proc Jpn Acad Ser B Phys Biol Sci. 2010; 86(6):588-610. doi:10.2183/pjab.86.588.

127.Lin X.Y., Wang H., Tan Y. Role of Hepatocyte Growth Factor in Wound Repair. Zhongguo Yi Xue Ke Xue Yuan Xue Bao. 2018; 40(6):822-826. doi: 10.3881/j.issn.1000503X.10246.

128. O'Leary R, Rerek M, Wood EJ. Fucoidan modulates the effect of transforming growth factor (TGF)-beta1 on fibroblast proliferation and wound repopulation in in vitro models of dermal wound repair. Biol Pharm Bull. 2004; 27(2):266-270. doi: 10.1248/bpb.27.266.

129. Charboneau AJ, Delaney JP, Beilman G. Fucoidans inhibit the formation of postoperative abdominal adhesions in a rat model [published correction appears in PLoS One. 2019; 14(1): e0211371]. PLoS One. 2018; 13(11): e0207797. doi: 10.1371/journal.pone.0207797.

130.Cashman JD, Kennah E, Shuto A, Winternitz C, Springate CM. Fucoidan film safely inhibits surgical adhesions in a rat model. J Surg Res 2011; 171:495. doi: 10.1016/j.jss.2010.04.043.

131.Chollet L., Saboural P., Chauvierre C., Villemin J.N., Letourneur D., Chaubet F. Fucoidans in Nanomedicine. Mar Drugs. 2016; 14(8). pii: E145. doi: 10.3390/md14080145.

132.Deniaud-Bouët E., Hardouin K., Potin P., Kloareg B., Hervé C. A review about brown algal cell walls and fucose-containing sulfated polysaccharides: Cell wall context, biomedical properties and key research challenges. Carbohydr. Polym. 2017; 175:395-408. doi: 10.1016/j.carbpol.2017.07.082.

133.Chang Y., Xue C., Tang Q., Li D., Wu X., Wang J. Isolation and characterization of a sea cucumber fucoidan-utilizing marine bacterium. Lett. Appl. Microbiol. 2010; 50:301-307. doi: 10.1111/j.1472-765X.2009. 02792.X

134.Citkowska A., Szekalska M., Winnicka K. Possibilities of Fucoidan Utilization in the Development of Pharmaceutical Dosage Forms. Mar Drugs. 2019; 17(8): pii: E458. doi: 10.3390/md17080458. 
135.Levendosky K, Mizenina O, Martinelli E, et al. Griffithsin and Carrageenan Combination to Target Herpes Simplex Virus 2 and Human Papillomavirus. Antimicrob Agents Chemother. 2015;59(12):7290-7298. doi:10.1128/AAC.01816-15.

136.Derby, N., Lal, M., Aravantinou, M. et al. Griffithsin carrageenan fast dissolving inserts prevent SHIV HSV-2 and HPV infections in vivo. Nat Commun 9, 3881 (2018). https://doi.org/10.1038/s41467-018-06349-0.

137.Zepon KM, Martins MM, Marques MS, Heckler JM, Dal Pont Morisso F, Moreira MG, Ziulkoski AL, Kanis LA. Smart wound dressing based on $\kappa$-carrageenan/locust bean gum/cranberry extract for monitoring bacterial infections. Carbohydr Polym. 2019; 206:362-370. doi: 10.1016/j.carbpol.2018.11.014.

138. Yegappan R, Selvaprithiviraj V, Amirthalingam S, Jayakumar R. Carrageenan based hydrogels for drug delivery, tissue engineering and wound healing. Carbohydr Polym. 2018; 198: 385-400. doi: 10.1016/ j. carbpol.2018.06.086.

139.Shankar S., Teng X., Li G., Rhim, J.-W. Preparation, characterization, and antimicrobial activity of gelatin/ZnO nanocomposite films. Food Hydrocolloids, 2015; 45: 264-271. carrageenan

140.Zia K.M., Tabasum S., Nasif M., Sultan N., Aslam N., Noreen A., Zuber M. A review on synthesis, properties and applications of natural polymer-based carrageenan blends and composites. International Journal of Biological Macromolecules, 2017; 96: 282-301. doi: 10.1016/j.ijbiomac.2016.11.095.

141.Cunha L., Grenha A. Sulfated seaweed polysaccharides as multifunctional materials in drug delivery applications. Marine Drugs, 2016; 14(3): 42.

142.Radiation Effects in Polymeric Materials. By Editors: V. Kumar, B. Chaudhary, V. Sharma and K. Verma. Cham, Switzerland, Springer, 2019. 412 p.

143.Tytgat L, Van Damme L, Ortega Arevalo MDP, et al. Extrusion-based 3D printing of photo-crosslinkable gelatin and $\kappa$-carrageenan hydrogel blends for adipose tissue regeneration. Int J Biol Macromol. 2019; 140:929-938. doi: 10.1016/j.ijbiomac.2019.08.124.

144.Li H, Tan YJ, Li L. A strategy for strong interface bonding by 3D bioprinting of oppositely charged $\kappa$-carrageenan and gelatin hydrogels. Carbohydr Polym. 2018; 198:261-269. doi: 10.1016/j.carbpol.2018.06.081.

145.Lokhande G., Carrow J.K., Thakur T., Xavier J.R., Parani M., Bayless K. J., Gaharwar A.K. Nanoengineered injectable hydrogels from kappa-carrageenan and two-dimensional nanosilicates for wound healing application. Acta Biomaterialia, 2018; 70: 35-47.

146.Singh D., Singh A., Singh R. Polyvinyl pyrrolidone/carrageenan blend hydrogels with nanosilver prepared by gamma radiation for use as an antimicrobial wound dressing. Journal of 
Biomaterials Science Polymer Edition, 2015; 26(17), 1269-1285. doi: 10.1080/09205063.2015.1087366.

147.El-Fawal G.F., Yassin A.M., El-Deeb N.M. The novelty in fabrication of polyvinyl alcohol/א-Carrageenan hydrogel with Lactobacillus bulgaricus extract as antiinflammatory wound dressing agent. AAPS PharmSciTech, 2017; 18(5), 1605-1616. doi: 10.1208/s12249-016-0628-6.

148.Schaude C., Fröhlich E., Meindl C., Attard J., Binder B., Mohr G. J. The development of Indicator cotton swabs for the detection of pH in wounds. Sensors (MDPI), 2017; 17(6): 1365. doi: 10.3390/s17061365.

149.Niar A.V., Raman M., Doble M. Cyclic $\beta-(1 \rightarrow 3)(1 \rightarrow 6)$ glucan/carrageenan hydrogels for wound healing applications. RSC Advances, 2016; 33(3): 98545-98553. doi: 10.1039/C6RA23386D.

150.Tamayol A., Akbari M., Zilberman Y., Comotto M., Lesha E., Serex L., Khademhosseini A. Flexible pH-Sensing hydrogel fibers for epidermal applications. Advanced Healthcare Materials, 2016; 5(6): 711-719. doi: 10.1002/adhm.201500553.

151.Tziveleka LA, Ioannou E, Roussis V. Ulvan, a bioactive marine sulphated polysaccharide as a key constituent of hybrid biomaterials: A review. Carbohydr Polym. 2019; 218:355-370. doi: 10.1016/j.carbpol.2019.04.074.

152.Manivasagan P, Oh J. Marine polysaccharide-based nanomaterials as a novel source of nanobiotechnological applications. Int $\mathrm{J}$ Biol Macromol. 2016; 82:315-327. doi: 10.1016/j.ijbiomac.2015.10.081.

153. Alves A, Pinho ED, Neves NM, Sousa RA, Reis RL. Processing ulvan into 2D structures: cross-linked ulvan membranes as new biomaterials for drug delivery applications. Int $\mathbf{J}$ Pharm. 2012; 426(1-2):76-81. doi: 10.1016/j.ijpharm.2012.01.021.

154.Kanno K., Akiyoshi K., Nakatsuka T., Watabe Y., Yukimura S., Ishihara H., Shin N., Kawasaki Y., Yano D. Biocompatible hydrogel from a green tide-forming chlorophyta. J. Sustainable Dev., 2012; 5(4): 38-45.

155.Toskas G., Hund R.D., Laourine E., Cherif C., Smyrniotopoulos V., Roussis V. Nanofibers based on polysaccharides from the green seaweed Ulva rigida. Carbohydr. Polym., 2011; 84: 1093-1102.

156.Kidgell J.T., Magnusson M., de Nys R., Glasson C.R.K. Ulvan: A systematic review of extraction, composition and function. Algal Research, 2019; 39: 101422. doi: 10.1016/j.algal.2019.101422.

157.Mata L., Magnusson M., Paul N.A. et al. The intensive land-based production of the green seaweeds Derbesia tenuissima and Ulva ohnoi: biomass and bioproducts. J Appl Phycol, 2016; 28: 365-375. doi: 10.1007/s10811-015-0561-1. 
158.GlassonaIan C.R.K., Sims I.M., Carnachan S.M., Nysa R., Magnusson M. A cascading biorefinery process targeting sulfated polysaccharides (ulvan) from Ulva ohnoi. Algal Research, 2017; 27: 383-391. doi: 10.1016/j.algal.2017.07.001.

159.Nardelli A.E., Chiozzini V.G., Braga E.S. et al. Integrated multi-trophic farming system between the green seaweed Ulva lactuca, mussel, and fish: a production and bioremediation solution. J Appl Phycol 2019; 31, 847-856. doi: 10.1007/s10811-018-1581-4.

160.Adrien A., Bonnet A., Dufour D., Baudouin S., Maugard T., Bridiau N. Pilot production of ulvans from Ulva sp. and their effects on hyaluronan and collagen production in cultured dermal fibroblasts. Carbohydr Polym. 2017; 157:1306-1314. doi: 10.1016/j.carbpol.2016.11.014.

161.Hardouin K., Bedoux G., Burlot A.-S., Donnay-Moreno C., Bergé J.-P., NyvallCollén P., Bourgougnon N., Enzyme-assisted extraction (EAE) for the production of antiviral and antioxidant extracts from the green seaweed Ulva armoricana (Ulvales, Ulvophyceae), Algal Res. 2016; 16:233-239. doi: 10.1016/j.algal.2016.03.013.

162. Rizk M.Z., El-Sherbiny M., Borai I.H., Ezz M.K., et al. Sulphated polysaccharides (SPS) from the green alga ulva fasciata extract modulates liver and kidney function in high fat diet-induced hypercholesterolemic rats. Int J Pharm Pharm Sci, 2016; 8: 43-55. https://www.researchgate.net/deref/http\%3A\%2F\%2Fcreativecommons.org\%2Flicenses\%2Fby $\% 2 \mathrm{~F} 4.0 \% 2 \mathrm{~F}$. 